\title{
Mixing of Asian mineral dust with anthropogenic pollutants over East Asia: a model case study of a super-duststorm in March 2010
}

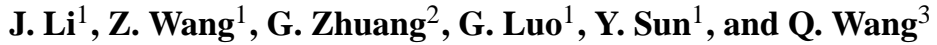 \\ ${ }^{1}$ LAPC, Institute of Atmospheric Physics, Chinese Academy of Sciences, Beijing, China \\ ${ }^{2}$ Center for Atmospheric Chemistry Study, Department of Environmental Science and Engineering, Fudan University, \\ Shanghai, China \\ ${ }^{3}$ Shanghai Environmental Monitoring Center, Shanghai, China
}

Correspondence to: Z. Wang (zifawang @mail.iap.ac.cn)

Received: 14 December 2011 - Published in Atmos. Chem. Phys. Discuss.: 27 January 2012

Revised: 14 August 2012 - Accepted: 14 August 2012 - Published: 21 August 2012

\begin{abstract}
Mixing of Asian mineral dust with anthropogenic pollutants allows pollutants (e.g. sulfate and nitrate) to be transported over longer distances (e.g. to the northern Pacific, even to North America) along with dust particles. This mixing therefore affects the atmospheric and oceanic environment at local, regional and even continental scales. In this study, we used a three-dimensional regional chemical transport model (Nested Air Quality Predicting Modeling System, NAQPMS) to examine the degree of mixing between Asian mineral dust and anthropogenic pollutants in a superduststorm event during 19-22 March 2010. Influences of the mixing processes on regional atmospheric environmental and oceanic biogeochemical cycles were also investigated. A comparison with measurements showed that the model reproduced well the trajectory of long-range dust transport, the vertical dust profile, and the chemical evolution of dust particles. We found that along-path mixing processes during the long-range transport of Asian dust led to increasingly polluted particles. As a result, $\sim 60 \%$ of the sulfate and 70 $95 \%$ of the nitrate in the downwind regions was derived from active mixing processes of minerals with pollutants sourced from the North China Plain and enhanced by transport over South China. This mixing had a significant impact on the regional-scale atmospheric composition and oceanic biogeochemical cycle. Surface $\mathrm{HNO}_{3}, \mathrm{SO}_{2}$ and $\mathrm{O}_{3}$ were decreased by up to $90 \%, 40 \%$ and $30 \%$, respectively, due to the heterogeneous reactions on dust particles. Fe solubility rose from $\sim 0.5 \%$ in the Gobi region to $\sim 3-5 \%$ in the northwestern Pacific, resulting from oxidization of $\mathrm{SO}_{2}$ on dust particles. Total Fe(II) deposition in the ocean region of East Asia
\end{abstract}

reached 327 tons during the 4-day dust event, and created a calculated primary productivity of $\sim 520 \mathrm{mgC} \mathrm{m}^{-2} \mathrm{~d}^{-1}$ in the Kuril Islands, which can support almost $100 \%$ of the observed mean marine primary productivity in spring in this region $\left(526 \mathrm{mgC} \mathrm{m}^{-2} \mathrm{~d}^{-1}\right)$.

\section{Introduction}

Over the last few decades, China has experienced urbanization and industrialization processes on an unprecedented scale. More than 120 cities have populations of more than one million. This rapid growth in such a short period of time has not only led to a remarkable increase in material wealth and a higher standard of living, but has also caused serious so-called "complicated air pollution", which means various types of pollution (e.g. acid rain, coal smog, photochemical smog, duststorm and haze) are present together in China (He et al., 2002). The chemical transformation and transport processes in this "complicated air pollution" make emissions controls more difficult. In particular, the interaction between gas and aerosols creates major challenges for policy makers. Therefore, approaches to reduce "complicated air pollution" and its impact on other regions have already become the research focus for Chinese environmental scientists.

The mixing of Asian mineral dust with anthropogenic pollutants is one of the major research issues. This is because extremely high levels of sulfur dioxide $\left(\mathrm{SO}_{2}\right)$ and nitrogen dioxide $\left(\mathrm{NO}_{2}\right)$ in China allow dust particles to take up high levels of both these pollutants, leading to the formation of 
water-soluble sulfate and nitrate (Jordan et al., 2003). Compared with pure secondary anthropogenic sulfate and nitrate, sulfate and nitrate on dust can be transported over much longer distances (e.g. to the northern Pacific, even to North America), (Duce, 1980; Wilkening et al., 2000) along with dust particles. These pollutants alter the photochemistry, acid deposition and oceanic primary productivity along the pathway of long-range transport, through chemical transformation and dry/wet deposition (Jordan et al., 2003; Zhuang et al., 2003; Tang et al., 2004). Consequently, studying the mixing of Asian mineral dust with anthropogenic pollutants is crucial for a detailed understanding of the impact of China's anthropogenic emissions on the atmospheric and oceanic environments at local, regional and even continental scales.

The mineralogy of Asian dust particles consists primarily of carbonates $\left(\mathrm{CaCO}_{3}\right)$, quartz $\left(\mathrm{SiO}_{2}\right)$, feldspars, micas, clays and hematite $\left(\mathrm{Fe}_{2} \mathrm{O}_{3}\right)$. Ca in Asian dust accounts for $39 \%$ of seven crustal elements ( $\mathrm{Si}, \mathrm{Al}, \mathrm{Mg}, \mathrm{Ca}, \mathrm{Na}$ and $\mathrm{K}$ ), in contrast with Saharan dust particles where Ca only takes up $17 \%$ (Krueger et al., 2004). The greater Ca concentration allows Asian dust particles to easily react with anthropogenic sulfuric and nitric acid, which consequently chemically alter the dust particles (Jordan et al., 2003). By collecting and analyzing aerosol samples over long time scales at North Pacific island stations, Zhuang et al. (1992) proposed a hypothesis for the coupling and feedback between natural iron $(\mathrm{Fe})$ and anthropogenic $\mathrm{S}$ in the atmosphere and ocean. In their hypothesis, the heterogeneous oxidation of $\mathrm{SO}_{2}$ to sulfate drives the acidification of dust particles. In highly acidic ambient aerosol solutions, Fe (III) in atmospheric dust particles is reduced to be $\mathrm{Fe}$ (II) with $\mathrm{OH}$ radical production. More $\mathrm{Fe}(\mathrm{II})$ could result in the marine production of more DMS which in turn provides more $\mathrm{SO}_{2}$ into the atmosphere. The more $\mathrm{SO}_{2}$ result in more acidic $\mathrm{SO}_{4}^{2-}$ aerosol on mineral dust and again more $\mathrm{Fe}(\mathrm{II})$. Charlson et al. (1987) suggested that the heterogeneous oxidation of $\mathrm{SO}_{2}$ to sulfate is a key step in this feedback between iron and sulfate. Furthermore, Mesekhidze et al. (2003) proposed that the $\mathrm{SO}_{2}$ from urban and industrial centers plays a key role in $\mathrm{Fe}$ mobilization in Asian mineral dust. Zhuang et al. (1992) believed that this hypothesis can explain high $\mathrm{Fe}(\mathrm{II})$ and non-sea salt sulfate (nss-sulfate) observed in aerosol samples at a remote pacific station (Midway, Hawaii). Zhuang et al. (1992) believed that this hypothesis can explain high Fe(II) and non-sea salt sulfate (nss-sulfate) observed in aerosol samples at a remote pacific station (Midway, Hawaii).

Partial evidence for Zhuang's hypothesis has been found in observations of Asian dust plume outflows in the Yellow Sea (East of China) and northwestern Pacific (a downwind region of China) since the late 1990s. Choi et al. (2001) reported that $\mathrm{SO}_{4}^{2-}, \mathrm{NO}_{3}^{-}, \mathrm{Ca}^{2+}$ and $\mathrm{Mg}^{2+}$ were the dominant water soluble ions in bulk dust aerosols in Seoul, and $\mathrm{SO}_{4}^{2-}$ and $\mathrm{NO}_{3}^{-}$ were primarily found in the coarse fraction associated with $\mathrm{Ca}^{2+}$ (Kim and Park, 2001). This is in contrast with non-dust observations suggesting that anthropogenic $\mathrm{SO}_{4}^{2-}$ and $\mathrm{NO}_{3}^{-}$ are associated with $\mathrm{NH}_{4}^{+}$in fine particles. Lidar observations showed that the aerosols were possibly an internal mixture of dust and sulfate during dusty days in the northeast Pacific (Sugimoto et al., 2002). Jordan et al. (2003) estimated that $43 \%$ of sulfate came from Asian dust particles during an intensive aircraft-based aerosol sampling program as part of TRACE-P. Aerosol samples on the NASA DC-8 aircraft also revealed that the capture of $\mathrm{SO}_{4}^{2-}$ and $\mathrm{NO}_{3}^{-}$by Asian mineral particles was accompanied by acid-mobilization of Fe (Meskhidze et al., 2003). This acid-mobilization can increase Fe solubility from $0.5 \%$ to $1-2 \%$ within 3-5 days (Meskhidze et al., 2003). Excellent correlation between the marine primary productivity observed at two remote sites in the northwestern Pacific and dust storm frequency in China seems to support their conclusion (Deng et al., 2008).

Numerical modeling is a very useful tool for estimating the degree of mixing of minerals with anthropogenic pollutants (Tie et al., 2005). Various models have been used to estimate the contribution of China's anthropogenic emissions to this mixing process by comparing model results and observations in regions downwind of China's emissions (e.g. Korea, Japan and the northwestern Pacific). Lasserre et al. (2008) developed a model for assessing this mixing. Using a regional model, Song and Carmichael (2001) estimated that chemical conversion of $\mathrm{SO}_{2}$ on the surface of dust particles accounted for $10-40 \%$ of $\mathrm{SO}_{4}^{2-}$ production in Asian dust plumes. Tang et al. (2004) found heterogeneous reactions on dust particles can produce $>20 \%$ of $\mathrm{SO}_{4}^{2-}$ and $>70 \%$ of $\mathrm{NO}_{3}^{-}$under heavy dust loadings over the northwestern Pacific. Luo et al. (2005) and Fan et al. (2006) also suggested that increasing $\mathrm{SO}_{2}$ emissions alone could have caused significant Fe mobilization in the Northern Hemisphere oceans. However, the lack of model evaluation in China (the major region where minerals mix with pollutants) leads to large uncertainties in their estimations. A recent dust model intercomparison (DMIP) study over Asia found that simulated dust emissions by 8 models ranged from 27 to $336 \mathrm{Tg}$ in a Asian dust event, although they agreed with each other in downwind regions, and suggested that modeling of dust transport and removal processes between China and Japan was one of the most important issues in improving dust modeling (Uno et al., 2006). In addition, greatly varied uptake coefficients are another origin of uncertainties (e.g. uptakes of nitric acid $\left(\mathrm{HNO}_{3}\right)$ varied greatly in the studies of Tang et al. (2004) and Tie et al. (2005), with values of 0.01 and 0.1 , respectively). Therefore, a simulation evaluated by observations in China is urgently needed for assessing the extent to which mineral dust mixes with China's anthropogenic emissions.

Recent studies have extended observations into China. Sun et al. (2005) found $\mathrm{SO}_{4}^{2-} / \mathrm{Al}$ and $\mathrm{NO}_{3}^{-} / \mathrm{Al}$ ratios in dust particles in Beijing (Fig. 1) were 60 and 8 times higher than those in surface soils of the Gobi Desert and Loess Plateau, respectively. They concluded that these high ratios in Beijing were 


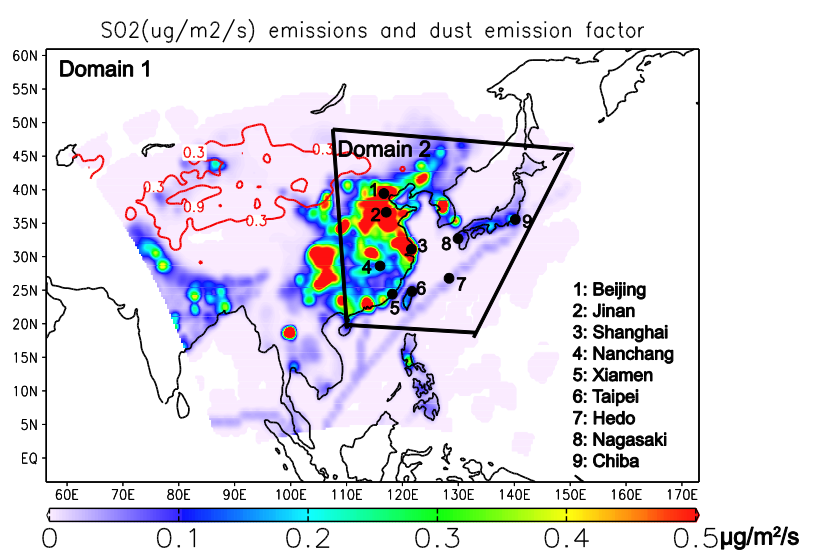

Fig. 1. Distribution of $\mathrm{SO}_{2}$ emission rate $\left(\mu \mathrm{g} \mathrm{m}^{-2} \mathrm{~s}^{-1}\right)$ in this study and modeling domain of NAQPMS. Also shown are the weighting factor of dust emissions ( $E$ in Eq. 2), red contours) and observed stations (solid cycles). The numerical characters mean the locations and name in the study.

attributed to the capture of $\mathrm{SO}_{2}$ or $\mathrm{HNO}_{3}$ by mineral dust during long-range transport (Sun et al., 2005). Meanwhile, $\mathrm{Fe}$ (II) in total Fe greatly increased, from $0.4 \%$ to $1.3-5.3 \%$, during the long-range dust transport in Beijing (Zhang et al., 2005). By applying positive matrix factorization (PMF) combined with the enrichment factors method, Yuan et al. (2008) suggested that dust particles brought Beijing a lot of sulfate, but little nitrate, which is opposite to other studies (Jordan et al., 2003). However, high concentrations of both sulfate and nitrate were observed in Xiamen, China (Fig. 1) during dusty days (Zhao et al., 2011). More evidence of the mixing of minerals with pollutants in China can be found in the literature (Zhang et al., 2003; Zhuang et al., 2003, 2010; Wang et al., 2011a). The above observations provide excellent opportunities for model simulations to estimate the extent to which dust mixes with China's anthropogenic emissions.

On 19-23 March 2010, a super-duststorm event occurred in China. In contrast to previous events, which have all occurred at mid-latitudes, this event covered the whole of eastern China from the Gobi desert $\left(45^{\circ} \mathrm{N}\right)$ to South China Sea. Even at Xiamen city $\left(24.5^{\circ} \mathrm{N}\right)$ in South China and on Dongsha Island $\left(20^{\circ} \mathrm{N}\right)$ in the South China Sea, aerosol concentrations reached $990 \mu \mathrm{g} \mathrm{m}^{-3}$ and $300 \mu \mathrm{g} \mathrm{m}^{-3}$, respectively, which are the highest levels in history (Wang et al., 2011b; Zhao et al., 2011). Remote sensing showed that this event lasted in eastern China for 4 days ( $\mathrm{Li}$ et al., 2011b), which allowed dust particles to mix thoroughly with China's anthropogenic emissions.

The goal of this study is to estimate the extent to which Asian aerosols mixed with China's pollutants in the dust episode of 19-23 March 2010. We utilized a regional chemical transport model (NAQPMS) and evaluated its performance by comparison with in-situ and remote sensing observations in China. We also assessed changes of gas concen- trations and inputs of $\mathrm{Fe}$ (II) to the ocean due to this mixing. In this paper, the description and validation of NAQPMS is presented in Sects. 2 and 3. Section 4 provides details of the mixing between dust particles and pollutants at the regional scale in East Asia. Section 4 also focuses on the chemical transformations on dust particles during transport, and calculates the impacts of mixing on concentrations of atmospheric constituents and on marine primary productivity by dry/wet deposition of $\mathrm{Fe}$ (II) to the ocean. In Sect. 5, impacts of uptake coefficients and dust irregular shapes on estimated results are discussed. And final conclusions are drawn in Sect. 6.

\section{Model description and setup}

\subsection{A brief description of the NAQPMS model}

The Nested Air Quality Prediction Modeling System (NAQPMS) utilized in this study is a fully modularized three-dimensional regional Eulerian chemical transport model, driven by the meteorological model WRF-ARW 3.2. NAQPMS reproduces the physical and chemical evolution of reactive pollutants by solving the mass balance equation in terrain-following coordinates ( $\mathrm{Li}$ et al., 2007, 2008; Wang et al., 2006). It includes advection, diffusion and convection processes, gas/aqueous/aerosol chemistry, and parameterization of dry/wet deposition. An accurate mass conservative, peak-preserving algorithm is used to deal with advection (Walcek and Aleksic, 1998). The vertical eddy diffusivity is parameterized based on a scheme by Byun and Dennis (1995). The dry deposition module is the parameterization of Wesely (1989). The wet deposition and aqueous-phase chemistry section was based on the RADM mechanism used in the CMAQ version 4.6 (available at http://www.cmascenter. org/). Carbon-Bond Mechanism Z (CBM-Z), which is composed of 133 reactions for 53 species, has been embedded into NAQPMS to calculate the gas chemistry (Zaveri and Peters, 1999). NAQPMS employs an aerosol thermodynamic model (ISORROPIAI1.7) to calculate the composition and phase state of an ammonia-sulfate-nitrate-chloride-sodiumwater inorganic aerosol (Nenes et al., 1998). A bulk yield scheme is used to deal with the formation of secondary organic aerosols (SOA) (Li et al., 2011a). Six SOAs, of which two are from anthropogenic precursors (toluene and higher aromatics) and four are from biogenic precursors (monoterpene and isoprene), are explicitly treated. Sea salt emissions ranging 0.43 to $10 \mu \mathrm{m}$ are calculated following Athanasopoulou et al. (2008) with 4 size bins. Aerosol optical depths are converted from mass concentrations using an externalmixture-based so-called "reconstructed extinction coefficient method" proposed by Malm et al. (2000) as part of the Integracy Monitoring of Projected Visual environment (IMPROVE) program. It has been widely applied in simulations on aerosol optical properties and showed a good performance in East Asia, particularly in China (Han et al., 2010). In this 


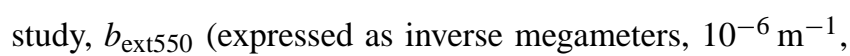
at $550 \mathrm{~nm}$ ), was calculated by Eq. (1):

$b_{\text {ext550 }}=3.0 \times f(\mathrm{RH})\left\{\left[\left(\mathrm{NH}_{4}\right)_{2} \mathrm{SO}_{4}\right]+\left[\mathrm{NH}_{4} \mathrm{NO}_{3}\right]\right\}+4.0$

$\times[\mathrm{OMC}]+10.0 \times[\mathrm{LAC}]+1.0 \times[\mathrm{SOIL}]+0.6 \times[\mathrm{CM}](1)$

where $f(\mathrm{RH})$ represents the hygroscopic growth factor or extinction enhancement factor resulting from water uptake on aerosols. OMC, LAC, SOIL and CM represent concentrations $\left(\mu \mathrm{g} \mathrm{m}^{-3}\right)$ of organic matter, light-absorbing carbon, soil aerosol and coarse mass, respectively.

\subsection{Description of a unique dust deflation module}

The generation of desert dust is critical in this study. Here, we applied a modified size-segregated dust deflation module designed by Wang et al. (2000) to simulate the long-range transport of Asian dust. The module was developed after detailed analysis of the meteorological conditions, landforms and climatology available in daily weather reports from about 300 local weather stations in northern China (Wang et al., 2000). It has been successfully applied in the simulations of dust long-range transport, impact of dust on acid rain and dustclimate interactions (Wang et al., 2002; Yue et al., 2010). Recently, Luo and Wang (2006) modified the mineral dust emission intensity $(F)$, considering soil categories, vegetation fraction percentages and snow/ice coverage, by introducing the following equation:

$F=C_{1} \times \frac{\rho_{\mathrm{a}}}{g} \times E \times u^{* 3}\left(1+\frac{u_{0}^{*}}{u^{*}}\right) \times\left(1-\frac{u_{0}^{* 2}}{u^{* 2}}\right) \times\left(1-\frac{\mathrm{RH}}{\mathrm{RH}_{0}}\right)$

where $F$ is the dust flux $\left(\mathrm{kg} \mathrm{m}^{-2} \mathrm{~s}^{-1}\right)$. The constant $C_{1}$ is set to $1.0 \times 10^{-5} \cdot \rho_{\mathrm{a}}\left(\mathrm{kg} \mathrm{m}^{-3}\right)$ and $\mathrm{g}\left(\mathrm{m}^{2} \mathrm{~s}^{-2}\right)$ are the air density and acceleration due to gravity. Weighting factor $(E)$ represents the uplifting capability of land surface, and reflects the impact of landuse categories, vegetation fractions and snow/ice coverage on dust fluxes. In the desert without vegetable and snow cover, dust particles are easily uplifted to the boundary layer, and $E$ is set to 1.0 . On the contrary, $E$ is set to 0.0 in evergreen forest. In this study, soil categories, vegetation fractions and snow/ice coverage are derived from Moderate Resolution Imaging Spectrometer (MODIS) data. Figure 1 shows the distribution of calculated $E$ in this study. $u^{*}$ and $u_{0}^{*}$ are the fraction and threshold friction velocities. $u_{*}^{0}$ is related to soil type, mineral particle size distribution, surface roughness and soil moisture. Here, $u_{0}^{*}$ is set to 0.45 , 0.35 and $0.6 \mathrm{~m} \mathrm{~s}^{-1}$ in the Gobi, China Loess and Hunshandak deserts, respectively. These values were obtained from observations by Zhu and Zhang (2010). $u_{0}^{*}$ in other dust source regions is set as $0.4 \mathrm{~m} \mathrm{~s}^{-1}$ as suggested by Yue et al. (2010). $\mathrm{RH}$ and $\mathrm{RH}_{0}$ represent relative humidity and its threshold value. In this study, $\mathrm{RH}_{0}$ is set to $40 \%$. The dust particle size is divided into 4 size bins covering the range $0.43-10 \mu \mathrm{m}$ in diameter $(0.43-1 \mu \mathrm{m} ; 1-2.5 \mu \mathrm{m} ; 2.5-5 \mu \mathrm{m}$ and $5-10 \mu \mathrm{m})$.

\subsection{Uptakes of anthropogenic gases on aerosol}

In this study, 28 heterogeneous reactions are considered when simulating the mixing of aerosols with pollutant gases. Table 1 lists the all reactive uptake coefficients, some of which consider the effects of relative humidity (e.g. reactions with nitric acid on dust particles). The first-order rate constant $\left(k_{\text {het }}\right)$ is calculated by uptake coefficients $(\gamma)$ and surface area density of particles $(A)$ using the following equation suggested by Jacob (2000):

$k_{\text {het }}=\left(\frac{r}{D_{\mathrm{g}}}+\frac{4}{c r}\right)^{-1} \times A$

where $r$ is the black carbon and sulfate mean radius, $D_{\mathrm{g}}$ is the gas phase diffusion coefficient, $c=\left(\frac{8 k T}{m}\right)^{0.5}$ is the mean molecular speed of the gas, $\gamma$ is the uptake coefficient and $A$ is the surface area density of the particles.

Depending on types of dust sample, experimental and analytical methods, measured uptake coefficient $(\gamma)$ on certain reaction usually varies greatly, in some cases several orders of magnitude. This could bring uncertainties to assess the mixing extents of dust and urban aerosols. Considering impact of dust mineralogy, we tried our best to select those values on China losses and Gobi desert which are potential sources to reduce the uncertainties due to $\gamma$. For example, the reaction $\mathrm{HNO}_{3}$ on dust particles in this study is experimental $\gamma$ on China Losses at $0 \%, 40 \%$ and $80 \%$ RH (Wei, 2010).

In this study, we compute uptakes of gases on mineral dust separately for each dust bin ( 4 bins from $0.43-10 \mu \mathrm{m}$ ) which is expected to reduce errors caused by coarse size distributions in previous studies, and maintain dust sulfate and dust nitrate as separate size-segregated components in the model. These dust-nitrate and dust-sulfate coat mineral dust particles by a shell on the surface of dust particles, and experience the same transport and deposition processes as the corresponding dust particles.

\subsection{Acid dissolution of iron containing mineral dust}

Mixing of urban acidic gases with mineral dust might result in an enhancement of iron mobilization in mineral dust plumes (Mesekhidze et al., 2003). To the extent that this mobilized iron is then acting as a limiting marine primary productivity. This would imply that iron mobilization is one of important indicators reflecting impacts of mixing processes on regional environment. Air pollution controls in China which reduced $\mathrm{SO}_{2}$ and $\mathrm{NO}_{\mathrm{x}}$ emissions might actually depress $\mathrm{C}$-uptake in pacific waters, and thus affect the regional climate.

A large number of studies have demonstrated that dissolved iron $(\mathrm{Fe}(\mathrm{II}))$ in surface seawater is the limiting nutrient factor for primary productivity in high-nitrate lowchlorophyll (HNLC) regions of ocean (Zhuang et al., 2003). However, Fe in surface soils of the Gobi deserts is found 
Table 1. Heterogeneous reactions and reactive uptake coefficients.

\begin{tabular}{|c|c|c|c|}
\hline No. & Heterogeneous reactions & $\gamma^{\mathrm{a}}$ & $\operatorname{Ref}^{b}$ \\
\hline HR1 & $\mathrm{N}_{2} \mathrm{O}_{5}+$ sulfate $\rightarrow 2 \mathrm{HNO}_{3}$ & $\begin{array}{l}\gamma=\alpha \times 10^{\beta} \\
\alpha=2.79 \times 10^{-4}+1.3 \times 10^{-4} \times \mathrm{RH} \\
-3.43 \times 10^{-6} \times \mathrm{RH}^{2}+7.52 \times 10^{-8} \times \mathrm{RH}^{3} \\
\beta=4 \times 10^{-2} \times(T-294)(T \geq 282 \mathrm{~K}) \\
\beta=-0.48(T<282 \mathrm{~K})\end{array}$ & 1 \\
\hline HR2 & $\mathrm{NO}_{3}+$ sulfate $\rightarrow \mathrm{HNO}_{3}$ & $3 \times 10^{-3}$ & 2 \\
\hline HR3 & $\mathrm{HO}_{2}+$ sulfate $\rightarrow 0.5 \mathrm{H}_{2} \mathrm{O}_{2}$ & $2.5 \times 10^{-1}$ & 3 \\
\hline HR4 & $\mathrm{OH}+$ sulfate $\rightarrow$ products & $2 \times 10^{-1}$ & 4 \\
\hline HR5 & $\mathrm{HCHO}+$ sulfate $\rightarrow$ products & $2.2 \times 10^{-2}$ & 5 \\
\hline HR6 & $\mathrm{O}_{3}+$ soot $\rightarrow$ products & $1.8 \times 10^{-4} \times e^{-\frac{1000}{T}}$ & 5 \\
\hline HR7 & $\mathrm{NO}_{2}+$ soot $\rightarrow \mathrm{HONO}$ & $3.3 \times 10^{-4}$ & 6 \\
\hline HR8 & $\mathrm{HNO}_{3}+$ soot $\rightarrow \mathrm{NO}_{2}$ & $2.1 \times 10^{-2}$ & 6 \\
\hline HR9 & $\mathrm{NO}_{2}+$ soot $\rightarrow 0.5 \mathrm{HONO}+0.5 \mathrm{HNO}_{3}$ & $3.0 \times 10^{-3}$ & 7 \\
\hline HR10 & $\mathrm{N}_{2} \mathrm{O}_{5}+$ soot $\rightarrow 2 \mathrm{HNO}_{3}$ & $5.0 \times 10^{-3}$ & 1 \\
\hline HR11 & $\mathrm{O}_{3}+$ dust $\rightarrow$ products & $2.7 \times 10^{-5}$ & 8 \\
\hline HR12 & $\mathrm{HNO}_{3}+$ dust $\rightarrow \mathrm{NO}_{3}^{-}$ & $\gamma=\frac{c \times \mathrm{RH}}{(1-\mathrm{RH}) \times(1-(1-c) \times \mathrm{RH})} \times 0.018(c=8)$ & $9,10^{\mathrm{c}}$ \\
\hline HR13 & $\mathrm{NO}_{2}+$ dust $\rightarrow 0.5 \mathrm{HONO}+0.5 \mathrm{HNO}_{3}$ & $2.1 \times 10^{-6}$ & 8 \\
\hline HR14 & $\mathrm{NO}_{3}+$ dust $\rightarrow \mathrm{HNO}_{3}$ & $1.0 \times 10^{-3}$ & 11 \\
\hline HR15 & $\mathrm{N}_{2} \mathrm{O}_{5}+$ dust $\rightarrow 2 \mathrm{HNO}_{3}$ & $3.0 \times 10^{-2}$ & 8 \\
\hline HR16 & $\mathrm{OH}+$ dust $\rightarrow$ products & $1.0 \times 10^{-1}$ & 8 \\
\hline HR17 & $\mathrm{HO}_{2}+$ dust $\rightarrow 0.5 \mathrm{H}_{2} \mathrm{O}_{2}$ & $2.0 \times 10^{-1}$ & 8 \\
\hline HR18 & $\mathrm{H}_{2} \mathrm{O}_{2}+$ dust $\rightarrow$ products & $\gamma=12 \times \mathrm{RH}^{2}-5.95 \times \mathrm{RH}+4.08$ & 12 \\
\hline HR19 & $\mathrm{SO}_{2}+$ dust $\rightarrow \mathrm{SO}_{4}^{2-}$ & $1 . \times 10^{-4}$ & 13 \\
\hline HR20 & $\mathrm{CH}_{3} \mathrm{COOH}+$ dust $\rightarrow$ products & $1.0 \times 10^{-3}$ & 8 \\
\hline HR21 & $\mathrm{CH}_{3} \mathrm{OH}+$ dust $\rightarrow$ products & $1.0 \times 10^{-5}$ & 8 \\
\hline HR22 & $\mathrm{HCHO}+$ dust $\rightarrow$ products & $1.0 \times 10^{-5}$ & 8 \\
\hline $\mathrm{HR} 23$ & $\mathrm{~N}_{2} \mathrm{O}_{5}+\mathrm{SSA} \rightarrow 2 \mathrm{HNO}_{3}$ & $\begin{array}{l}5.0 \times 10^{-3}(\mathrm{RH}<62 \%) \\
3.0 \times 10^{-2}(\mathrm{RH} \geq 62 \%)\end{array}$ & 1 \\
\hline HR24 & $\mathrm{NO}_{3}+\mathrm{SSA} \rightarrow \mathrm{HNO}_{3}$ & $1.0 \times 10^{-3}$ & 7 \\
\hline HR25 & $\mathrm{HO}_{2}+\mathrm{SSA} \rightarrow 0.5 \mathrm{H}_{2} \mathrm{O}_{2}$ & $2.0 \times 10^{-1}$ & 7 \\
\hline HR26 & $\mathrm{SO}_{2}+\mathrm{SSA} \rightarrow \mathrm{SO}_{4}^{2-}$ & $\begin{array}{l}5.0 \times 10^{-3}(\mathrm{RH}<50 \%) \\
5.0 \times 10^{-2}(\mathrm{RH} \geq 50 \%)\end{array}$ & 14 \\
\hline HR27 & $\mathrm{NO}_{3}+\mathrm{SSA} \rightarrow \mathrm{NO}_{3}^{-}$ & $1.7 \times 10^{-2}$ & 15 \\
\hline HR28 & $\mathrm{HNO}_{3}+\mathrm{SSA} \rightarrow \mathrm{NO}_{3}^{-}$ & $5.0 \times 10^{-1}$ & 16 \\
\hline
\end{tabular}

a $\gamma$ is the reaction probability; $T$ is temperature (K), RH is relative humidity (\%).

b References: 1. Evans and Jacob (2005); 2: Bauer et al. (2004); 3: Kanaya et al. (2009); 4: Tie and Brasseur (1999); 5: Tie et al. (2005); 6: Kotamarthi et al. (2001); 7: Jacob (2000); 8: Zhu et al. (2010); 9: Vlasenko et al. (2006); 10: Wei (2010); 11: Martin et al. (2003); 12: Pradhan et al. (2010); 13: Phadnis and Carmichael (2000); 14: Song and Carmichael (2001); 15: Gratpanche (1996); 16: Guimbaud et al. (2002).

c Vlasenko et al. in refrence 9\# suggested the BET isotherm has a similar shape with the experimental $\gamma$ as a function of RH. Wei et al. in refrence 10\# reported $\gamma$ on China Losses at $0 \%, 40 \%$ and $80 \% \mathrm{RH}$. So $\gamma$ in this study is calculated by the BET isotherm forced by $\gamma$ values reported by Wei (2010).

mainly in the form of undissolved hematite ( $\alpha$-Fe2O3). Acid mobilization which reduce undissolved hematite to dissolved $\mathrm{Fe}$ (II) is thought as one of possible mechanisms (Mesekhidze et al., 2003). Fan et al. (2006) proposed a two-step mechanism for the acid-mobilization of iron in mineral dust particles. In this mechanism, formation of dissolved $\mathrm{Fe}$ (Fe(II)) experiences two processes: sulfate coating and dissolution of iron (hydr)oxide on the coated dust aerosols. The sulfate coating process can be achieved by the heterogeneous oxi- dation of $\mathrm{SO}_{2}$ and $\mathrm{HNO}_{3}$ (HR12 and HR19 in Table 1), and represents the acidification of mineral dust surface. Dissolution of iron (hydr)oxide represents the mass transfer from insoluble $\mathrm{Fe}$ to dissolved $\mathrm{Fe}$ in acid highly acidic ambient aerosol solutions. Three types iron/dust are included: fresh, coated and dissolved (for Fe). In this study, we used this twostep mechanism to reproduce the impact of mixing processes on Fe mobilization. 
In the first step, gas uptakes convert dust particles from fresh to coated by the heterogeneous reactions HR12 and HR19. The rate coefficient represents how many fresh dust particles are converted into coated particles and is calculated from $k_{\mathrm{S}}\left[\mathrm{SO}_{2}\right]+k_{n}\left[\mathrm{HNO}_{3}\right]$, where $k_{\mathrm{S}}$ and $k_{n}$ represent the first order rates of HR19 and HR12. In the second step, $\mathrm{Fe}$ (III) in the coated dust is transferred to dissolved $\mathrm{Fe}(\mathrm{Fe}(\mathrm{II}))$. The production rate of $\mathrm{Fe}(\mathrm{II})$ is calculated from $R_{\mathrm{Fe}}=R_{\mathrm{d}} A n M / w$, where $R_{\mathrm{Fe}}$ is grams of Fe dissolved per gram of Fe(III) per second, $R_{\mathrm{d}}$ is the dissolution rate per unit surface area, $A$ is the specific surface area of hematite $\left(\mathrm{m}^{2} \mathrm{~g}^{-1}\right), n=2$ (moles Fe/moles hematite), $M$ is the gram-molecular weight of $\mathrm{Fe}$, and $w$ is the mass fraction of Fe in hematite (i.e. 0.7). Here, $R_{\mathrm{d}}$ and $A$ are set as $1 \times 10^{-10} \mathrm{~mol} \mathrm{~m}^{-2} \mathrm{~s}^{-1}$ and $100 \mathrm{~m}^{2} \mathrm{~g}^{-1}$ as suggested by Fan et al. (2006) and Duckworth and Martin (2001). These values correspond to an e-folding time of 6-10 days for dissolution. Besides the heterogeneous chemistry, the effects of radiation process and cloud process on Fe-mobilization are also considered based on the scheme devised by Luo et al. (2005). Here the Fe solubility is assumed to have a lower limit of $0.5 \%$ (Fan et al., 2006).

Overall, five categories of aerosols are explicitly treated in our model: (1) anthropogenic aerosols (sodium-chloridesulfate-nitrate-ammonium, black carbon and organic carbon) (2): dust particles; (3) sea salt, (4) dust-sulfate and dust-nitrate, (5) sea salt-nitrate and sulfate. The aerosol and gas gases are coupled through (1) gas chemistry module, (2) aqueous chemistry module, (3) heterogeneous chemistry module, (4) gas-aerosol partitioning of inorganic compounds. In the category of anthropogenic aerosols, sulfate, nitrate and ammonium are in the form of $\mathrm{NaCl}, \mathrm{Na}_{2} \mathrm{SO}_{4}, \mathrm{NaNO}_{3}, \mathrm{NH}_{4} \mathrm{NO}_{3},(\mathrm{NH} 4)_{2} \mathrm{SO}_{4}, \mathrm{NH}_{4} \mathrm{Cl}$, $\mathrm{NH}_{4} \mathrm{HSO}_{4}, \mathrm{NaHSO}_{4}$, and $\left(\mathrm{NH}_{4}\right)_{3} \mathrm{H}\left(\mathrm{SO}_{4}\right)_{2}$ and internally mixed each other. They are in fine mode with a lognormal size distribution. Anthropogenic aerosols are externally mixed with the other categories of aerosols (dust and sea salt). Previous studies shows that the assumption of external mixture of anthropogenic aerosols with dust or sea salt is reasonable (Maxwell-Meier et al., 2004; Tang et al., 2004; Song et al., 2005).

\subsection{Model setup}

Figure 1 shows the NAQPMS model domain used in this study, which is composed of two nested domains. The coarser domain is $7760 \times 6160 \mathrm{~km}$ on a Lambert conformal map projection with $80-\mathrm{km}$ grid resolution. The nested domain is divided into $148 \times 160$ horizontal grids with $20 \mathrm{~km}$ resolution. Vertically, the model uses 20 terrain-following layers from the surface to $20 \mathrm{~km}$ a.s.l., with the lowest 10 layers below $3 \mathrm{~km}$.

The first meteorological guess fields and boundary conditions for the coarse domain for every $6 \mathrm{~h}$ are obtained from NCAR/NCEP FNL reanalysis data $\left(1^{\circ} \times 1^{\circ}\right)$. Nudging, or four dimensional data assimilation (FDDA) (OTTE, 2008), consisting of 6-h 3-D analyses of temperature, water vapor mixing ratio and horizontal wind components for both domains, and 6-h surface analyses of horizontal wind components for the coarse domain, were used with nudging coefficients of $3.0 \times 10^{-4}$ for the wind, temperatures and humidity fields of the coarse and nested domains. In this study, The Yonsei University (YSU) Boundary Layer (BL) scheme is used for calculating BL height. The surface layer and land surface schemes are the MM5 similarity and Noah Land Surface schemes, respectively.

The anthropogenic emissions of air pollutants (fossil fuels, biofuels and industrial emissions) in Asia are derived from the year 2006 bottom-up Regional Emission inventory in Asia (REAS) data at $\left(0.5^{\circ} \times 0.5^{\circ}\right)$ resolution (Ohara et al., 2007). The initial and boundary conditions are taken from a global chemical transport model MOZART-V2.4 with $2.8^{\circ}$ resolution. The mass fraction of $\mathrm{Fe}(\mathrm{III})$ in dust particles is set as $2.8 \%$ in this study, following Zheng et al. (1994).

The simulation started at 00:00 UTC on 10 March 2010 and ran through to the 24 March 2010. The first 5 days are regarded as the spin-up period, used to reduce the influence of initial conditions.

\section{Model validation}

Before validating concentrations of simulated dust particles and pollutants, we compare the predicted and observed hourly averaged meteorological variables (temperature, relative humidity and wind) during 19-23 March 2010 (figure not shown). The results show the model successfully reproduced the synoptic features of the meteorological variables, notably the change of wind direction from northward to southward during the dust episode.

\subsection{Observational data}

In this study, a combination of aspaceborne instruments, backscatter lidars, and mass aerosol instruments is used to evaluate the model's ability in simulating horizontal and vertical distributions of aerosols over East Asia during the dust event.

The Moderate Resolution Imaging Spectroradiometer (MODIS) field of AOD at $550 \mathrm{~nm}$ is obtained from the MODIS/AQUA Deep Blue Collection 005. MODIS is one of the most widely used passive satellite instruments in aerosol remote sensing. In this study, the daily level 3 AOD product at $550 \mathrm{~nm}$ (Ver5.1) was retrieved as an average value for an area defined by a $1^{\circ} \times 1^{\circ}$ square cell. The expected accuracy level over land is $\pm 0.05 \pm 0.15 \times$ AOD (Remer et al., 2005). Previous validations suggest that MODIS is capable of deriving AOD over land and ocean within expected uncertainty (Song et al., 2001; Cheng et al., 2012). 
Table 2. Statistical summary of comparisons of the model results with observations ${ }^{\mathrm{a}}$.

\begin{tabular}{llrrrrrrr}
\hline & & $N$ & $\overline{C_{\mathrm{m}}}$ & $\overline{C_{\mathrm{o}}}$ & $r$ & MB & RMSE & NME (\%) \\
\hline \multirow{2}{*}{ AOD550 } & Modis & 5701 & 0.60 & 0.65 & 0.64 & -0.05 & 0.52 & 56.0 \\
\hline \multirow{2}{*}{$\mathrm{SO}_{2}$} & Shanghai & 211 & 8.3 & 13.1 & 0.56 & -4.8 & 9.78 & 42.4 \\
& Beijing & 231 & 15.3 & 11.1 & 0.58 & 4.2 & 9.36 & 57.3 \\
\hline \multirow{2}{*}{$\mathrm{NO}_{2}$} & Shanghai & 240 & 13.2 & 35.9 & 0.49 & -22.0 & 26.1 & 62.0 \\
& Beijing & 197 & 21.0 & 21.2 & 0.67 & -0.2 & 9.93 & 42.7 \\
\hline \multirow{2}{*}{$\mathrm{PM}_{10}^{\mathrm{b}}$} & Beijing & 9 & 217.5 & 236.6 & 0.91 & -19.1 & 174.9 & 43.9 \\
& Jinan & 9 & 213.2 & 160.6 & 0.82 & 52.6 & 203.0 & 47.6 \\
& Shanghai & 9 & 137.7 & 182.2 & 0.94 & -44.5 & 89.4 & 42.6 \\
& Taipei & 117 & 64.8 & 70.4 & 0.80 & -5.6 & 38.5 & 52.0 \\
& Xiamen & 9 & 116.9 & 154.7 & 0.91 & -37.8 & 110.1 & 67.6 \\
& Nanchang & 9 & 204.7 & 238.8 & 0.86 & -34.1 & 129.7 & 73.5 \\
\hline
\end{tabular}

${ }^{\text {a }} N$ is the number of observed samples, $\overline{C_{\mathrm{m}}}, \overline{C_{\mathrm{o}}}, r, \mathrm{MB}, \mathrm{RMSE}$ and NME represent the mean modeled and observed values, correlation coefficient, mean bias, root mean square error and normalized mean error. Units of $\mathrm{SO}_{2}, \mathrm{NO}_{2}$ and $\mathrm{PM}_{10}$ are ppbv, ppbv and $\mu \mathrm{g} \mathrm{m}^{0-3}$, respectively. AOD550 is unitless.

${ }^{\mathrm{b}}$ Observed $\mathrm{PM}_{10}$ is dauly mean values, except Taipei which is an hourly mean value.

The aerosol backscatter data at Nagasaki, Chiba and Hedo shown in Fig. 1 is taken from the National Institute of Environmental Studies (NIES) lidar network (http://www-lidar. nies.go.jp/). In this ground-based lidar network over Asia, Mie-lidar extinction coefficients of non-spherical Asian dust are measured by the two-wavelength Mie-scattering lidar which has three channels and measures the backscattering at 1064 and $532 \mathrm{~nm}$ and the depolarization at $532 \mathrm{~nm}$. Vertical profiles averaged for $5 \mathrm{~min}$ are recorded every $15 \mathrm{~min}$. The height resolution was $6 \mathrm{~m}$ and the profiles are recorded up to 6-km.

Surface mass aerosol concentrations are determined by the Chinese air pollution index (API) which is officially reported for the principal pollutant among $\mathrm{SO}_{2}, \mathrm{NO}_{2}$ and $\mathrm{PM}_{10}$ (particles on the order of $\sim 10 \mu \mathrm{m}$ or less) (http://www.sepa.gov. $\mathrm{cn} /$ english/air_s.php3). API is calculated from daily averaged concentration (from 12:00 the day before to 12:00 on this day). During the study period, $\mathrm{PM}_{10}$ were always the prevailing pollutant in observation stations shown in Fig. 1, which allowed us to validate simulated $\mathrm{PM}_{10}$ mass concentrations. In this study, we use a polynomial regression to derive the $\mathrm{PM}_{10}$ mass loading from Chinese API, which has been already validated in the study of Lasserre et al. (2008). Note that API has an upper limit of 500, which means this value of $600 \mu \mathrm{g} \mathrm{m}^{-3}$ is a "saturation" maximum value.

$$
\begin{aligned}
& \mathrm{PM}_{10}\left(\mu \mathrm{g} \mathrm{m}^{-3}\right)=8 \times 10^{-6}(\mathrm{API})^{3}-87 \times 10^{-3}(\mathrm{API})^{2} \\
& +36706(\mathrm{API})-12127 .
\end{aligned}
$$

\subsection{Comparison with satellite retrievals}

Figure 2 presents the aerosol optical depth (AOD550) at $550 \mathrm{~nm}$ retrieved by MODIS (available at http://gdata1.sci.gsfc.nasa.gov/daac-bin/G3/gui.cgi?

instance_id=MODIS_DAILY_L3) and the AOD550 simu-
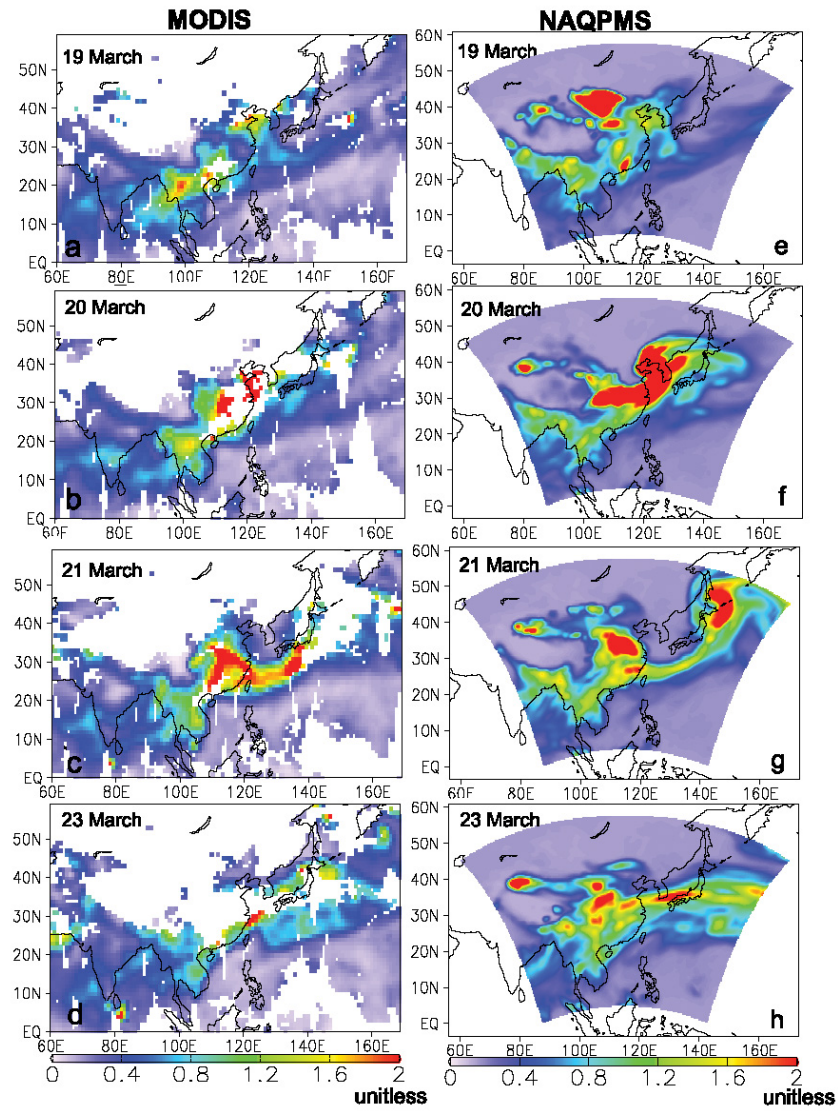

Fig. 2. MODIS-derived (left panel) and simulated AOD550 (right panel) during 19-23 March 2010. The white color in left panel indicates cloud contaminations. 
lated by NAQPMS during the 19-23 March 2010. Table 2 shows a series of statistical measures of agreements or disagreements between the simulation and observation. In general, the simulation reproduced the long-range transport of dust particles and anthropogenic aerosols over East Asia reasonably well over the study period. The correlation coefficients between model and satellite reach 0.64 . On 19 March, a duststorm episode started over the Gobi desert, as shown in Fig. 2e. This was associated with the formation of a strong Siberian-Mongolian high pressure system and a much stronger westerly wind in the Gobi, which entrained desert sand into the atmosphere (figure not shown). Unfortunately, MODIS data are missing over the Gobi due to either the lack of interorbital coverage or cloud contamination (Fig. 2a). However, the aerosol index measured by OMI (Ozone Monitoring Instrument) captured this outbreak of dust deflation over the Gobi (Li et al., 2011b). On 20 March, both the model and MODIS revealed that dust particles moved southeasterly to the North China Plain, the Gulf of Bohai and the Korean peninsula (Fig. 2b, f), where AOD550 was generally greater than 2 . On 21 March, the dust plume and cold front advanced further, reaching southern China (including Xia'men City) and Taiwan. Over the ocean, a narrow plume extended from Taiwan to the southwest of Japan. Due to relatively calm winds associated with the southeastward-moving high, dust particles still accumulated in central China and the Yangtze River delta (Fig. 2c, g). On 23 March, MODIS showed a relatively high AOD500 belt in the mid-latitudes, which we attribute to the combination of weakened dust and anthropogenic particle (e.g. BC, sulfate and nitrate) concentrations. This pattern is well reproduced by the simulation, which indicates good model performance with respect to both dust and anthropogenic particles.

\subsection{Comparison with ground-based observations}

Simulated concentrations of $\mathrm{PM}_{10}$ (particles on the order of $\sim 10 \mu \mathrm{m}$ or less) at six stations covering most of east China $\left(20-40^{\circ} \mathrm{N}\right)$ are compared with observations in Fig. 3. Different from other five sites, daily $\mathrm{PM}_{10}$ at Taipei is directly calculated using the 24-hourly averaged values instead of calculated values from Chinese API. As shown in Fig. 3, the model yielded good agreement with observations. The correlation coefficients and Normalized Mean Errors range from $0.8-0.95$ and $40-70 \%$, respectively (Table 2 ). As we expected, dust particles dominated the peak $\mathrm{PM}_{10}$ concentrations at these six sites in the dust event. Concentrations of $\mathrm{PM}_{10}$ abruptly increased on 20, 21 and 22-23 March in north China (Beijing and Jinan), the Yangtze River Delta (Shanghai and Nanchang) and south China (Xiamen and Taipei), respectively. The model correctly captured this pattern and showed a similar peak magnitude (e.g. in Taipei, Shanghai, and Nanchang). In Beijing and Jinan, the model slightly overestimated the peak. This is attributed to the imposed upper limit of API $\left(600 \mu \mathrm{g} \mathrm{m}^{-3}\right)$. However, other observations by

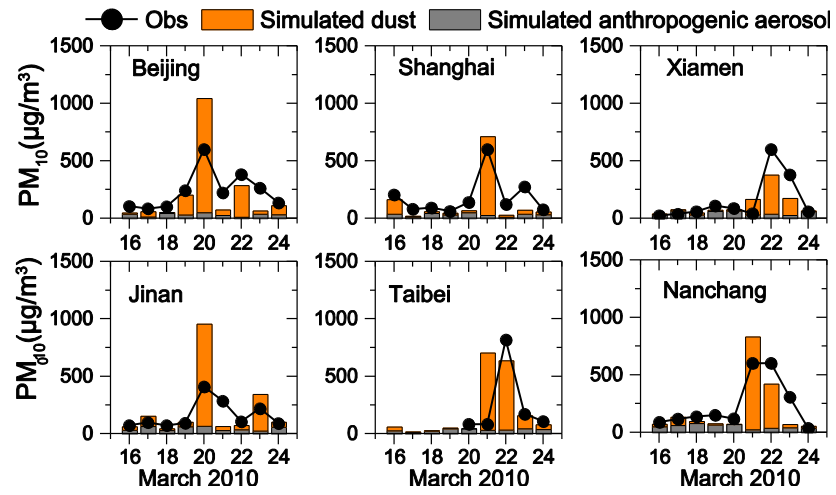

Fig. 3. Observed daily mean $\mathrm{PM}_{10}\left(\mu \mathrm{g} \mathrm{m}^{-3}\right)$ (black) and simulated daily mean dust (orange bars) and anthropogenic aerosols $\left(\mu \mathrm{g} \mathrm{m}^{-3}\right)$ (gray bars) in $\mathrm{PM}_{10}$ at six stations in China during 15-24 March 2010.

Zhang (H. Zhang, Peking University, China) revealed a peak of $3000 \mathrm{\mu g} \mathrm{m}^{-3}$ hourly concentrations (unpublished data), which are consistent with this simulation $\left(3300 \mu \mathrm{g} \mathrm{m}^{-3}\right)$. The simulation under predicted observed $\mathrm{PM}_{10}$ in Xiamen city, probably due to the stronger simulated deposition processes.

Lidar observations provide a good opportunity to evaluate the model's ability to predict vertical aerosol profiles. Figure 4 shows the observed and simulated vertical profiles of dust extinction coefficients during 15-24 March 2010. The two-wavelength Mie-scattering lidar observations (1064 nm and $532 \mathrm{~nm}$ ) are taken from the National Institute for Environmental Studies (NIES), Japan (http://www-lidar.nies. go.jp/). Clearly, the simulation agrees well with the overall evolution of the Lidar extinctions pattern. During the 19-22 March dust episode, the dust plume at three stations was constrained below $3 \mathrm{~km}$ and maintained a rather homogeneous profile. At Nagasaki and Hedo, another dust event on 19 March in the $1-3 \mathrm{~km}$ layer was accompanied by observations of a few dust particles on the ground. The model also captured this phenomenon.

Figure 5 compares observed and simulated $\mathrm{SO}_{2}$ and $\mathrm{NO}_{2}$ in Beijing and Shanghai during 15-24 March 2010. The model agrees with observations quite well, except for a significant underestimation of $\mathrm{NO}_{2}$ in Shanghai. The correlation coefficients are in the range 0.49-0.67. In particular, the decrease of $\mathrm{SO}_{2}$ and $\mathrm{NO}_{2}$ concentrations in the dust episode is captured by the model. The underestimation of $\mathrm{NO}_{2}$ in Shanghai is caused by the uncertainties of the REAS emission inventory $\left(0.5^{\circ} \times 0.5^{\circ}\right)$ in the Yangtze River Delta.

The model's ability to simulate sulfate and nitrate in nondust and dust periods is critical in assessing the mixing extent in this study. Figure 6 presents a comparison of simulated and observed sulfate and nitrate in Shanghai and Xiamen during the pre-dust, dust and after-dust periods in base case. Both the model and observations show that $\mathrm{SO}_{4}^{2-}$ and $\mathrm{NO}_{3}^{-}$significantly increased by factors of 2-3 times those in the pre-dust 

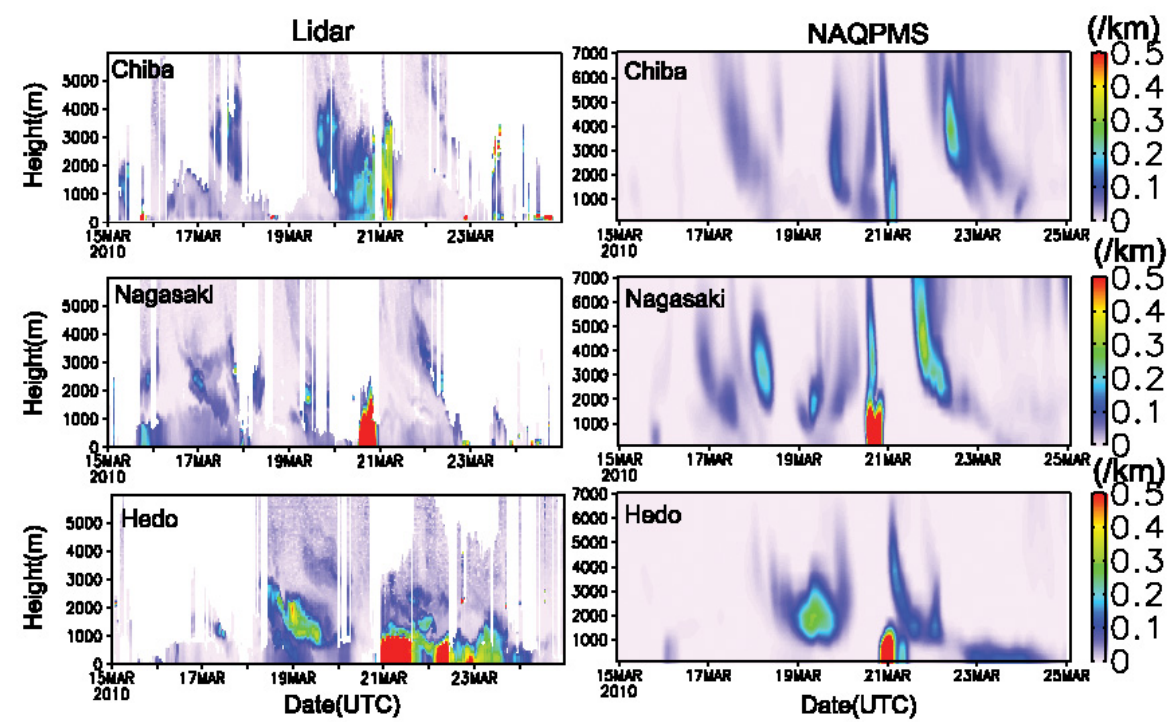

Fig. 4. Lidar measurements (532 nm) (left panel) and simulations (550 nm) (right panel) of extinction coefficients during 15-24 March 2010 at Chiba, Nagasaki and Hedo.
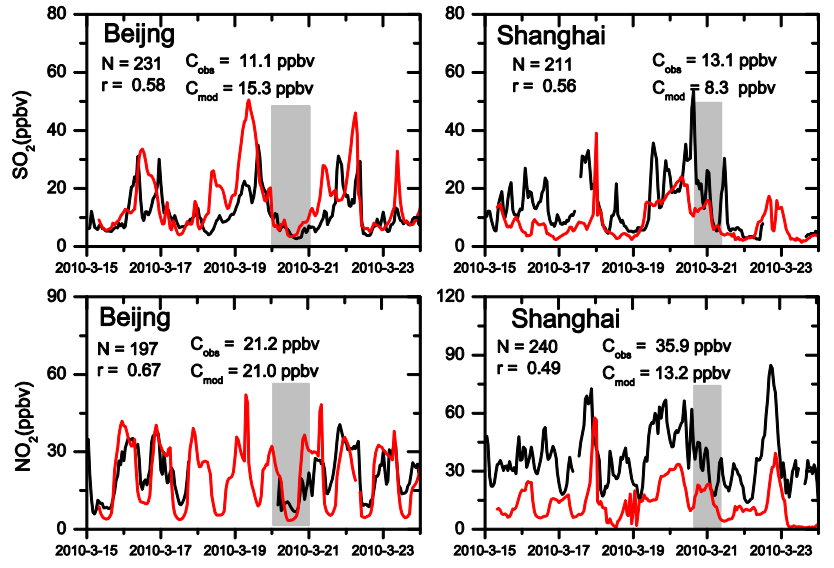

Time (BJT)

- Obs - Mod

TIme (BJT)

Fig. 5. Observed (black) and simulated (red) concentrations (ppbv) of $\mathrm{SO}_{2}$ (upper panel) and $\mathrm{NO}_{2}$ (lower panel) at Beijing (left panel) and Shanghai (right panel) during 15-24 March 2010. $N$ and $r$ represent numbers of paired samples and correlation coefficients, respectively. $C_{\mathrm{obs}}$ and $C_{\text {mod }}$ are average concentrations of observed and modeled species. The gray shades are the periods in the duststorm episode at two cities.

and after-dust periods at both sites. The simulation clearly indicates that the mixing of minerals with anthropogenic pollutants during the long-range transport played the dominant role in this increase, while anthropogenic $\mathrm{SO}_{4}^{2-}$ and $\mathrm{NO}_{3}^{-}$particles decreased along with their precursors $\left(\mathrm{SO}_{2}\right.$ and $\mathrm{NO}_{2}$ ) during the duststorm (Fig. 5). In the next section, we will discuss where the mixing of minerals with pollutants occurred (Figs. 7 and 8). Figure 6 also shows that the simula-

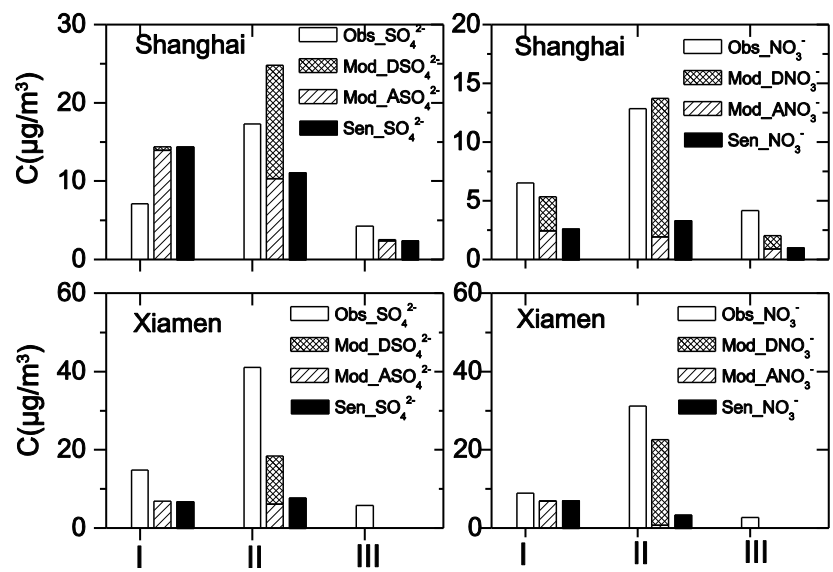

Fig. 6. Observed and simulated sulfate (left panel) and nitrate (right panel) at Shanghai (upper) and Xiamen (lower) during pre-dust (I), dust (II) and after-dust (III) period. $\mathrm{DSO}_{4}^{2-}$ and $\mathrm{DNO}_{3}^{-}$(same as below) are sulfate and nitrate captured by dust particles by heterogeneous chemistry, respectively. $\mathrm{ASO}_{4}^{2-}$ and $\mathrm{ANO}_{3}^{-}$represent the sulfate and nitrate particles by anthropogenic emissions. Sen_SO ${ }_{4}^{2-}$ and Sen_NO $\mathrm{NO}_{3}^{-}$represent simulated sulfate and nitrate in sensitivity simulation (no mixing processes between dust and anthropogenic pollutants). Observations at Xiamen are from Zhao et al. (2011).

tion underestimated the concentration of sulfate at Xiamen. This was caused by the underestimation of dust particle concentrations (as shown in Fig. 3). In fact, the simulated mass fraction of sulfate $(5.2 \%)$ in the total particles is consistent with observations $(4.8 \%)$.

Unfortunately, few observations of the size distribution of dust particles are available for this dust episode, although we 


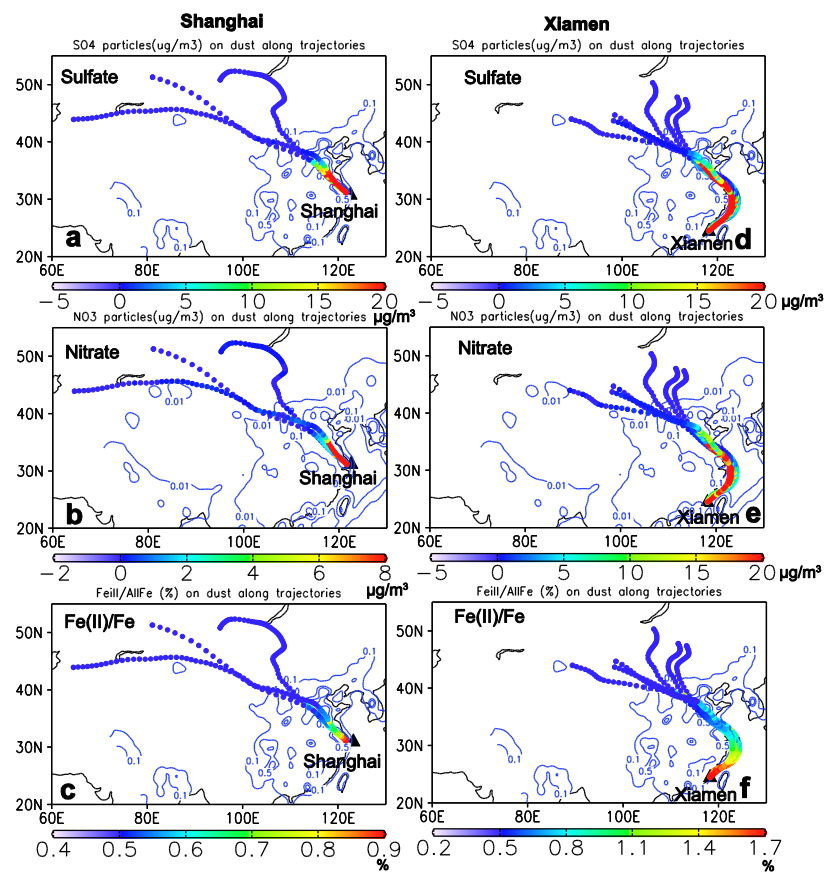

Fig. 7. Simulated sulfate (a, d) and nitrate (c, e) $\left(\mu \mathrm{g} \mathrm{m}^{-3}\right)$ captured by dust particles by heterogeneous chemistry along the 3-day backtrajectories at Shanghai and Xiamen during the dusty periods. Also shown is the mass fraction of dissolved $\mathrm{Fe}(\mathrm{Fe}(\mathrm{II}))$ in total $\mathrm{Fe}(\mathbf{e}$, f). The lines in colored lines represent the locations of air masses arrived at Shanghai and Xiamen during dusty days. The colors in colored lines represent the concentration of dust-sulfate and dustnitrate $\left(\mu \mathrm{g} \mathrm{m}^{-3}\right)$ and the mass fraction of dissolved $\mathrm{Fe}(\mathbf{e}, \mathbf{f})$. The blue contours represent the $\mathrm{SO}_{2}(\mathbf{a}, \mathbf{c}, \mathbf{d}, \mathbf{f})$ and $\mathrm{NO}_{\mathrm{x}}(\mathbf{b}, \mathbf{e})$ emission rate $\left(\mu \mathrm{g} \mathrm{m}^{-2} \mathrm{~s}^{-1}\right)$.

were able to collect fine and coarse particles from Shanghai and Xiamen (Table 3). These results showed the deposited particles coarsened as the plume moved south. The mass fraction of fine particles in Xiamen was twice of that in Shanghai. The model reproduced this pattern reasonably well. The simulated fine particle fraction $(47.9 \%)$ in Xiamen was very close to the observation ( $43 \%$ ). However, the model overestimated the mass fraction of fine particles in Shanghai. This is likely caused by the local re-suspension of deposited dust particles. Shanghai is closer to the dust source regions than Xiamen, and hence depositions contained more coarse particles. The strong wind in the dust episode may have re-entrained more coarse deposited particles into the atmosphere in Shanghai. Yuan et al. (2008) found that this re-suspension contributed 10-30\% of TSP (Total suspended particles) in Beijing. Most dust models, including NAQPMS in this study, fail to reproduce the re-suspension process.

In general, the above model validation indicates that NAQPMS is capable of reproducing the temporal and spatial distributions of observed dust particles and anthropogenic pollutants. It can also reproduce the chemical evolution of
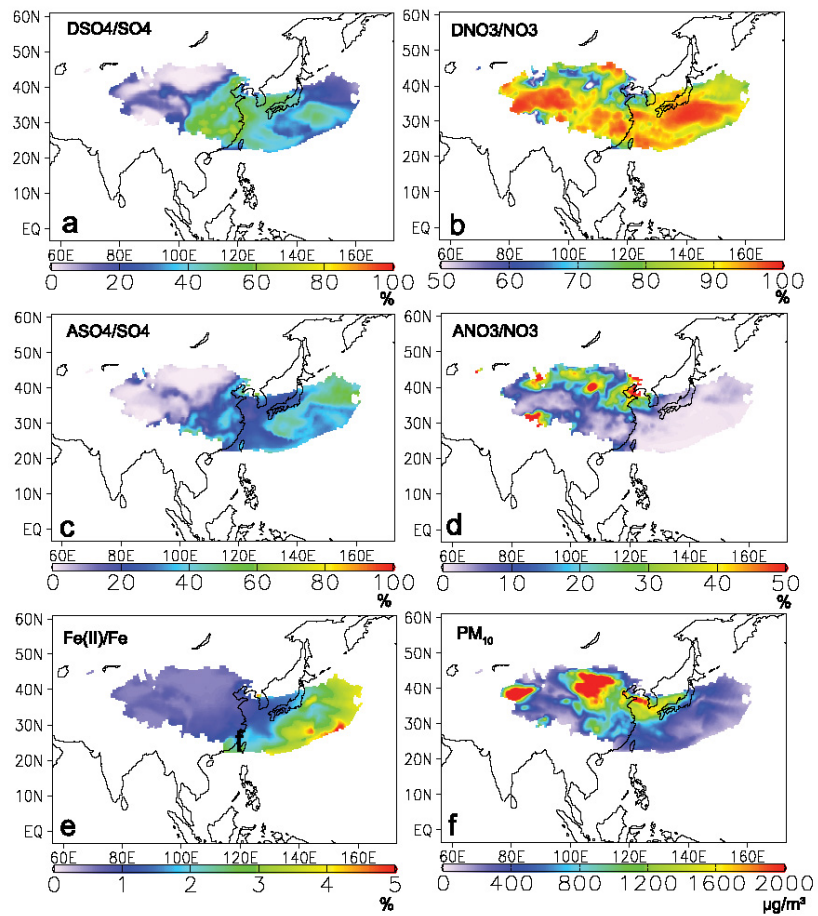

Fig. 8. Percentages of surface $\mathrm{DSO}_{4}^{2-}$ (a), $\mathrm{DNO}_{3}^{-}$(b), $\mathrm{ASO}_{4}^{2-}$ (c), $\mathrm{ANO}_{3}^{-}$(d) in total sulfate and nitrate during dusty periods over East Asia. Also shown are the fraction (\%) of $\mathrm{Fe}(\mathrm{II})$ in total $\mathrm{Fe}(\mathbf{e})$ and surface $\mathrm{PM}_{10}$ concentration $\left(\mu \mathrm{g} \mathrm{m}^{-3}\right)$ (f).

pollutants on dust particles. The reasonable performance provides some confidence in the model-derived results.

\section{Results}

\subsection{Level of mixing between mineral dust and pollutants}

As shown in Fig. 6, $\mathrm{SO}_{4}^{2-}$ resulting from the mixing of minerals with pollutants contributed more than $50 \%$ to the total sulfate in both Shanghai and Xiamen. Figure 7 shows the chemical evolution of $\mathrm{SO}_{4}^{2-}, \mathrm{NO}_{3}^{-}$and dissolved $\mathrm{Fe}$ along the back-trajectories during dusty days. The back trajectories are calculated by a Hybrid Single-Particle Lagrangian Integrated Trajectory (HYSPLIT v4) model based on WRF output with $80 \mathrm{~km}$ resolution (http://ready.arl.noaa.gov/HYSPLIT.php). For Shanghai, Fig. 7a-c shows dust particles stayed fresh and experienced no significant mixing with pollutants until they arrived on the North China Plain $\left(30-40^{\circ} \mathrm{N}, 110-120^{\circ} \mathrm{E}\right)$. The concentration of $\mathrm{SO}_{4}^{2-}$ taken up by dust particles significantly increased from $5 \mu \mathrm{g} \mathrm{m}^{-3}$ to $20 \mu \mathrm{g} \mathrm{m}^{-3}$ when the air mass reached the North China Plain. Both $\mathrm{NO}_{3}^{-}$on dust particles and $\mathrm{Fe}$ solubility show a similar pattern to $\mathrm{SO}_{4}^{2-}$. This indicates that high concentrations of anthropogenic pollutants on the North China Plain extensively coated these fresh dust 
Table 3. Fractions of fine and coarse particles at Shanghai and Xiamen during the dust episode. Observations at Xiamen are from Zhao et al. (2011).

\begin{tabular}{llcc}
\hline & & Obs & Mod \\
\hline \multirow{2}{*}{ Shanghai } & Fine $(<2.5 \mu \mathrm{m})$ & 18.9 & 33.2 \\
& Coarse $(>2.5 \mu \mathrm{m})$ & 81.1 & 66.8 \\
\hline \multirow{2}{*}{ Xiamen } & Fine $(<2.5 \mu \mathrm{m})$ & 43.0 & 47.9 \\
& Coarse $(>2.5 \mu \mathrm{m})$ & 57.0 & 52.1 \\
\hline
\end{tabular}

particles transported from the Gobi desert, due to heterogeneous reactions (Table 1). The fraction of $\mathrm{Fe}(\mathrm{II})$ in total $\mathrm{Fe}$ in Shanghai was in the range $0.8-1.5 \%$, which was less than previously observed values in a duststorm event in Beijing in April 2002 (1.3-5.3\%) (Zhang et al., 2005). This is likely to be due to the underestimation of the dissolution rate of $\mathrm{Fe}$ on dust particles $\left(R_{\mathrm{d}}\right)$ in this study. The different transport pathway between two episodes is another likely cause. In our study, after the air mass passed Shanghai, mixed dust particles were transported to South China (e.g. Xiamen) along the coast line, where high relative humidity promoted the heterogeneous reactions. Consequently, anthropogenic gases $\left(\mathrm{SO}_{2}\right.$ and $\mathrm{HNO}_{3}$ ) were more rapidly converted to $\mathrm{SO}_{4}^{2-}$ and $\mathrm{NO}_{3}^{-}$ on the dust particles. The fraction of Fe(II) reached 1.6-5.3\% in Xiamen, which indicates that mixing in South China was more active than in North China.

Similarly to the fraction of $\mathrm{Fe}$ (II) in total $\mathrm{Fe}$, the fractions of $\mathrm{SO}_{4}^{2-}$ and $\mathrm{NO}_{3}^{-}$captured by dust particles in total sulfate and nitrate are regarded as indices of the degree of mixing. Figure 8 shows the spatial distributions of the percentages (at the surface) of $\mathrm{SO}_{4}^{2-}$ and $\mathrm{NO}_{3}^{-}$captured by dust particles in total sulfate and nitrate masses during the dusty period. Fe(II) in total $\mathrm{Fe}$ is also shown. Here the dusty days are defined as the periods with total dust levels greater than $100 \mathrm{\mu g} \mathrm{m}^{-3}$, as suggested by Tang et al. (2004). It was found that $\mathrm{SO}_{4}^{2-}$ mixing with minerals contributed over $60 \%$ to total sulfate over eastern China and its downwind regions (northwestern Pacific), while its contribution was only $10-20 \%$ in the Gobi. The contribution of mixed $\mathrm{NO}_{3}^{-}$was $70-95 \%$ over the Gobi, eastern China and northwestern Pacific, which indicates that the level of mixing of $\mathrm{NO}_{3}^{-}$was higher than that of $\mathrm{SO}_{4}^{2-}$. This is partially due to the higher $\mathrm{HNO}_{3}$ uptake (HR12 in Table 1) on dust particles than that of $\mathrm{SO}_{2}$ (HR19 in Table 1), particularly in South China and the northwestern Pacific with high RH conditions (Jordan et al., 2003). The more complicated origin of $\mathrm{SO}_{4}^{2-}$ is likely to be another cause. In the semi-arid area of the Chinese Loess Plateau, sulfate usually covers $0.01-0.45 \%$ of soils or sands. In plumes with high dust loadings (i.e. dust source regions), the emitted mineral dust significantly contributes to total sulfate mass, which decreases the fraction of mixed sulfate. Our results for $\mathrm{SO}_{4}^{2-}$ are higher than those in previous studies. For example, Tang et al. (2004) estimated that dust enhanced sulfate by up to
$25 \%$ during a duststorm event in 2001. This indicates the strong mixing intensity of the duststorm event during 19-22 March 2010.

\subsection{Regional dust influences}

In order to investigate the influences of dust on the regional atmospheric and oceanic environment, a sensitivity simulation without mixing processes was performed. The difference between the sensitivity and base simulation reveals the influence of dust.

\subsubsection{Influences on concentrations of atmospheric tracer gases}

As well as aerosol compositions, the mixing of minerals with anthropogenic pollutants also alters the regional-scale concentrations of gaseous pollutants. Figure 9 shows the averaged influence of dust on surface $\mathrm{HNO}_{3}, \mathrm{O}_{3}$ and $\mathrm{SO}_{2}$ during 19-22 March 2010. The average $\mathrm{HNO}_{3}$ decrease due to heterogeneous reactions was 20-90\%, with the strongest decrease occurring in western China and in the Pacific to the south and east of Japan (up to 80-90\%) (Fig. 9a). The distribution of the $\mathrm{SO}_{2}$ decrease was similar to that of $\mathrm{HNO}_{3}$, but its impact was smaller (5-40\%) (Fig. 9c). Moreover, the impact area was much smaller. Surface $\mathrm{NO}_{2}$ are decreased 5$60 \%$ due to the heterogeneous reactions (HR13). The band of large decrease is in the western Pacific which is consistent with $\mathrm{SO}_{2}$. For $\mathrm{O}_{3}$, the decrease was in the range 5-30\% (Fig. 9b). An interesting point is that the influences of dust in polluted regions (e.g. the North China Plain: $30-40^{\circ} \mathrm{N}$ and $110-120^{\circ} \mathrm{E}$ ) were much smaller than those in remote regions. This is because high emission rates and complex photochemical systems on the North China Plain can offset part of their heterogeneous losses. Our estimations are consistent with the study of Tang et al. (2004), who estimated that surface $\mathrm{HNO}_{3}, \mathrm{SO}_{2}$ and $\mathrm{O}_{3}$ decreased by $20 \%, 20 \%$ and $95 \%$, respectively, due to heterogeneous reactions on dust particles.

\subsection{2 $\mathrm{Fe}(\mathrm{II})$ deposition and its potential influences on marine primary productivity}

A large number of studies have demonstrated that dissolved iron $(\mathrm{Fe}(\mathrm{II}))$ in surface seawater is the limiting nutrient factor for primary productivity in high-nitrate low-chlorophyll (HNLC) regions of ocean. Deposition of Asian mineral dust is thought to be the major source of $\mathrm{Fe}(\mathrm{II})$ in the Pacific. The $\mathrm{Fe}$ (II) deposited into the ocean may substantially affect ocean productivity, and by altering the uptake of carbon dioxide through the ocean, may even affect the global greenhouse effect (Zhuang et al., 2003).

The oxidation of $\mathrm{SO}_{2}$ and $\mathrm{HNO}_{3}$ on dust particles during the long-range transport largely enhances dissolved $\mathrm{Fe}$ deposition in Pacific. Observations show that this oxidation increased $\mathrm{Fe}$ (II) mass fraction in total $\mathrm{Fe}$ from $0.4 \pm 0.3 \%$ in Gobi to $1.3-2.6 \%$ in the offshore region (Zhuang et al., 1992, 

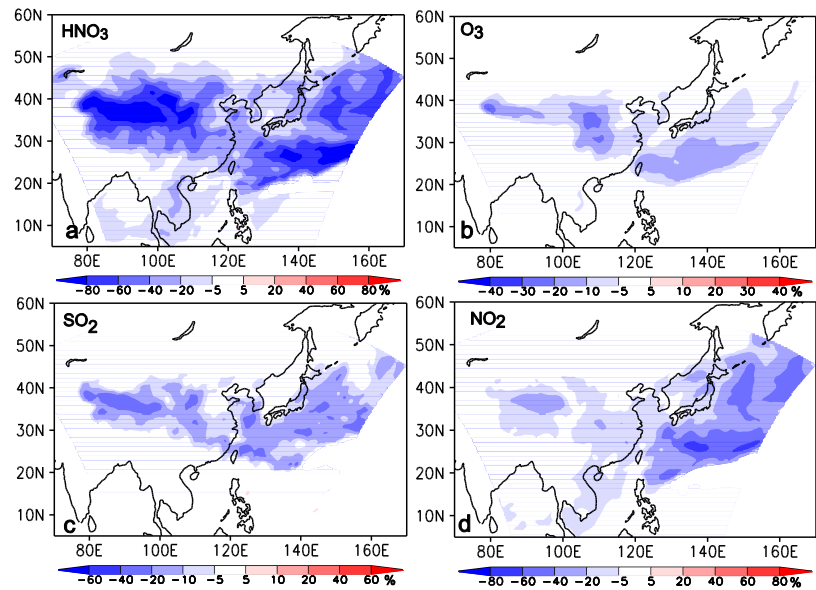

Fig. 9. Averaged dust influences (\%) on surface $\mathrm{HNO}_{3}$ (a), $\mathrm{O}_{3}$ (b), $\mathrm{SO}_{2}$ (c) and $\mathrm{NO}_{2}$ (d) concentrations over East Asia during 19-22 March 2010.

2003). Over the remote mid-Pacific, Fe(II) on Asian dust particles continued rising, to 5-10\%. Figure $8 \mathrm{c}$ shows the simulated mass fraction of $\mathrm{Fe}(\mathrm{II})$ in total $\mathrm{Fe}$ on dust particles in this study. The simulation captures this observed increase of Fe solubility with distance from dust source regions (i.e. the Gobi) well.

Figure 10 shows simulated dry, wet and total deposition of $\mathrm{Fe}$ (II) during this duststorm event. In order to isolate the impact of mixing processes on $\mathrm{Fe}(\mathrm{II})$ deposition, $\mathrm{Fe}(\mathrm{II}) \mathrm{de}$ position calculated in a sensitivity simulation without mixing processes is summarized in Table 4.

$\mathrm{Fe}$ (II) deposition in the ocean off East Asia ranged from 20 to $100 \mu \mathrm{g} \mathrm{m}^{-2}$ (Fig. 10a). The largest depositions occurred in the East China Sea $\left(40-60 \mu \mathrm{g} \mathrm{m}^{-2}\right)$, and in the Sea of Japan and the Kuril Islands $\left(100 \mu \mathrm{g} \mathrm{m}^{-2}\right)$, which comprised dry deposition (Fig. 10b) and wet deposition (Fig. 10c), respectively. As shown in Fig. 10b and c, dry deposition dominated the total deposition of $\mathrm{Fe}$ (II) close to the Chinese mainland, while wet deposition played a more important role in the far downwind ocean. Table 4 lists atmospheric deposition fluxes of $\mathrm{Fe}$ (II) to the ocean in base and sensitivity simulations. Clearly, the mixing of minerals with anthropogenic pollutants significantly increased the deposition of Fe(II).

Assuming that all the $\mathrm{Fe}$ (II) transported and deposited into oceans are bioavailable to phytoplankton. The input can be converted to carbon uptake by using a cellular $\mathrm{Fe}: \mathrm{C}$ ratio of $10 \mu \mathrm{mol} \mathrm{mol}^{-1}$ in the subarctic Pacific(e.g. the Kuril Islands: $150^{\circ} \mathrm{E}, 45^{\circ} \mathrm{N}$ ) where observed concentration of dissolved $\mathrm{Fe}$ (e.g. the Kuril Islands: $150^{\circ} \mathrm{E}, 45^{\circ} \mathrm{N}$ ) was about $0.2 \mathrm{nmol} 1^{-1}$ (Sunda and Huntsman, 1997). If we neglect removal by abiotic scavenging, our simulated $100 \mu \mathrm{g} \mathrm{m}^{-2} \mathrm{Fe}$ (II) deposition (over 4 days) in the Kuril Islands can create a marine primary productivity of $\sim 520 \mathrm{mgC} \mathrm{m}^{-2} \mathrm{~d}^{-1}$, which can support almost $100 \%$ of the observed mean marine primary produc-
Table 4. Atmospheric deposition Fluxes of Fe(II) to the ocean in the model domain during 19-22 March 2010 in the base (mixing processes) and sensitivity (no mixing processes) simulations.

\begin{tabular}{lccc}
\hline & $\begin{array}{c}\text { Dry } \\
\text { deposition }\end{array}$ & $\begin{array}{c}\text { Wet } \\
\text { deposition }\end{array}$ & $\begin{array}{c}\text { Total } \\
\text { deposition }\end{array}$ \\
\hline Base(ton) & 128 & 199 & 327 \\
Sensitivity(ton) & 51 & 20 & 71 \\
\hline
\end{tabular}

tivity in spring in this region $\left(526 \mathrm{mgC} \mathrm{m}^{-2} \mathrm{~d}^{-1}\right.$ ) (Imai et al., 2002). This indicates that dissolved Fe deposition mostly affected the marine primary productivity during this duststorm event. Our results also support previous studies which claimed subarctic Pacific is one of the major HNLC regions in the world and inadequate dissolved iron (Fe(II)) input was the limiting nutrient factor (Martin et al., 1988; Zhuang et al., 2003).

\section{Discussion}

\subsection{Uncertainties in the modeling of mixing between mineral dust and pollutants}

\subsubsection{Uncertainty in uptake coefficients}

Previous studies show that large uncertainties in the uptake coefficients $(\gamma)$ exist in laboratory studies, which could bring uncertainties to evaluate the impact of mineral dust on the tropospheric chemistry. Zhu et al. (2010) suggested that differences of uptake coefficients of $\mathrm{SO}_{2}$ and $\mathrm{HNO}_{3}$ on mineral dust (HT12 and HR19) are several orders of magnitude (HR12: $5.0 \times 10^{-7} \sim 2.6 \times 10^{-4}$; HR19: $1 \times 10^{-3} \sim 1.7 \times$ $10^{-1}$ ). In this study, we make use of the sensitive analysis to examine the uncertainties caused by HR12 and HR19. In order to cover the factor of uncertainties reported by Zhu et al. (2010), simulations in which one heterogeneous reaction (HR12 or HR19) was calculated individually with either the "lower limit" or "upper limit" are performed. This uncertainty $(U)$ was calculated by the following formulation:

$U=\left|\frac{y_{\gamma \text { (upper) }}-y_{\gamma \text { (lower) }}}{y_{\lambda \text { (base) }}}\right|$

where $y_{\gamma \text { (upper) }}, y_{\gamma \text { (lower) }}$ and $y_{\gamma \text { (base) }}$ represents the impacts of mineral dust on pollutants under conditions with upper limit, lower limit and values in Table 1, respectively.

Figure 11 presents the observed and simulated sulfate and nitrate at Shanghai and Xiamen during the dusty period in simulations with base, upper limit and little limit of $\gamma_{\mathrm{hno3}}$ (HR19) and $\gamma_{\mathrm{so} 2}$ (HR12). Clearly, the simulated nitrate and sulfate strongly depended on uptake coefficients. At Shanghai, the simulated nitrate and sulfate in base case where $\gamma$ values are taken from Table 1 were very close to observations. This indicates $\gamma_{\mathrm{hno} 3}$ and $\gamma_{\mathrm{so} 2}$ in this study is suitable 


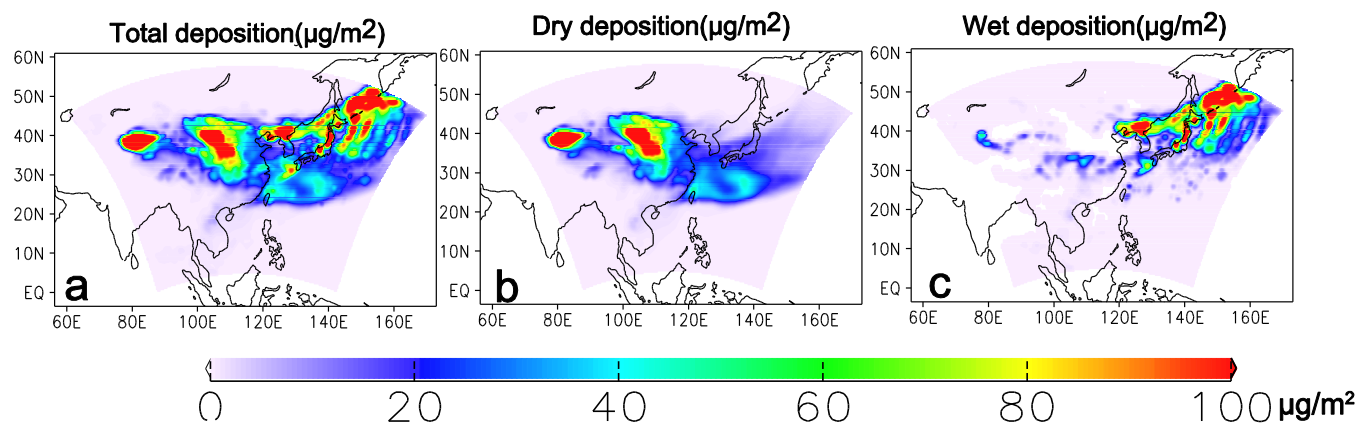

Fig. 10. Simulated (a) total deposition $\left(\mu \mathrm{g} \mathrm{m}^{-2}\right)$, (b) dry deposition $\left(\mu \mathrm{g} \mathrm{m}^{-2}\right)$, (c) wet deposition $\left(\mu \mathrm{g} \mathrm{m} \mathrm{m}^{-2}\right)$ of Fe(II) over East Asia during 19-22 March 2010.

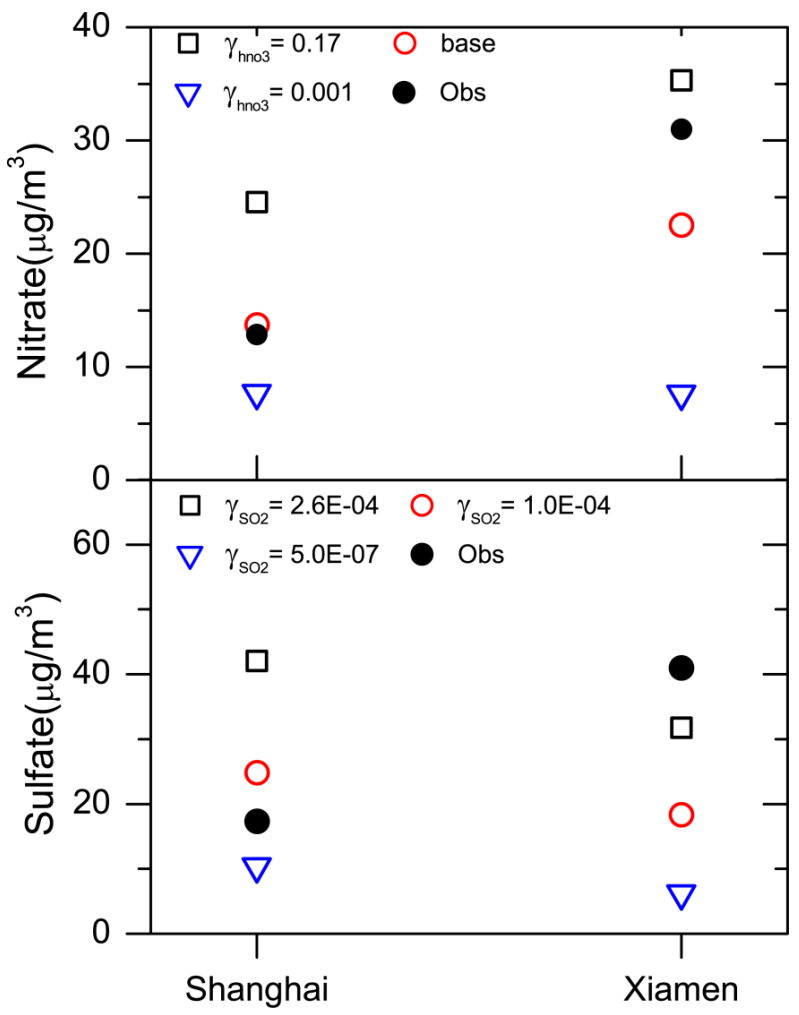

Fig. 11. Observed and simulated sulfate and nitrate at Shanghai and Xiamen during the dusty period in simulations with base, upper limit and lower limit of uptake coefficients of HR19 and HR12.

for this dust event. The upper limit of $\gamma_{\mathrm{hno} 3}$ and $\gamma_{\mathrm{so} 2}$ overestimated sulfate and nitrate in Shanghai, whereas the lower limit was not efficient enough. At Xiamen, although the simulated nitrate and sulfate concentrations in upper limit of $\gamma$ agreed with observations, the fraction of these inorganic components in dust particles indeed overestimated the observations. This is because the simulated dust concentrations were lower than observation (Fig. 3). The uncertainties of nitrate calculated by Eq. (5) reach $143 \%$ and $127 \%$ at Shang- hai and Xiamen, respectively. For sulfate, Shanghai and Xiamen were $218 \%$ and $209 \%$.

\subsubsection{Uncertainty in dust shapes}

It is known that mineral dust particles have irregular shapes. Okada et al. (2001) found that most of the dust particles in China $(0.2-4 \mu \mathrm{m})$ can be considered as ellipsoid characterized by an aspect ratio of $\sim 1.5$ (ratio between longer and short axis of an ellipse fitted to the particle outline). So the assumption of spherical particles in this study might cause errors because irregular particles could have different surface areas with sphere particles.

In this study, a method correcting surface area of irregular shapes was used to evaluate the impact of dust shapes on the heterogeneous reactions (Giroux, 2003). In this method, surface area of irregular particle can be calculated by a sphericity factor $\left(\phi_{\mathrm{p}}\right)$ in the formula:

$S_{\mathrm{p}}=S / \varphi_{\mathrm{p}}$

$S=\pi\left(\frac{6 V_{\mathrm{p}}}{\pi}\right)^{2 / 3}$

where $S$ and $S_{\mathrm{p}}$ represent the surface area of spherical and irregular particle, respectively. $V_{\mathrm{p}}$ is the particle volume. When $\phi_{\mathrm{p}}$ is equal to 1.0 , the particle is sphere, and when it is equal to 0.1 , the particle is elongated.

The sphericity factor $\left(\phi_{\mathrm{p}}\right)$ is expressed in terms of aspect ratio $(\lambda)$ as the following formula:

$\varphi_{\mathrm{p}}=\frac{2 \lambda^{2 / 3}}{1+\frac{\lambda^{2}}{\sqrt{\lambda^{2}-1}} \arcsin \left(\sqrt{1-\frac{1}{\lambda^{2}}}\right)}$

In China deserts (Taklamakan desert, Gobi), observed aspect ratio of dust is $\sim 1.5$ (Okada et al., 2001). So $\phi_{\mathrm{p}}$ is calculated to be 0.97 , which means surface areas errors caused by irregular shape are less than $5 \%$. 


\subsection{Implications on regional atmosphere}

From a photochemical perspective, heterogeneous chemistry on mineral dust surfaces that directly affects gaseous $\left(\mathrm{NO}_{2}\right.$, $\mathrm{HNO}_{3}$ and $\mathrm{O}_{3}$ ) is of great importance. By altering the complex set of photochemical reactions of $\mathrm{O}_{3}$ and its precursors, the heterogeneous pathway perturbs photochemical oxidant $\left(\mathrm{OH}\right.$ and $\left.\mathrm{HO}_{2}\right)$ and thus atmospheric oxidation capacity (Bian et al., 2003). Furthermore, the heterogeneous pathway may impact the self-cleaning of many atmospheric primary pollutants (VOCs) and formation of secondary pollutants. In this study, mineral dust decreased $\mathrm{HNO}_{3}$ and $\mathrm{NO}_{2}$ concentrations by up to $80-90 \%$ and $40 \%$, respectively. Indirect ozone due to $\mathrm{HNO}_{3}$ uptake likely exceeds direct heterogeneous uptake of $\mathrm{O}_{3}$. This indicates that heterogeneous chemistry on mineral dust surfaces may be of importance in the chemical balance of the troposphere over East Asia.

The chemical interactions between the gas and dust particles are able to result in increased amounts of sulfate and nitrate in the aerosol, and a change in size distributions of these anthropogenic pollutants. Under non-dust conditions, the sulfate formation is controlled by the nucleation of $\mathrm{H}_{2} \mathrm{SO}_{4}$ and $\mathrm{H}_{2} \mathrm{O}$ and coagulation processes, and then concentrates in the fine particles. At a large dust loading, the sulfate formation due to surface uptake becomes dominant and its mass exhibits a maximum in coarse mode (Jordan et al., 2003). As shown in Fig. 8, sulfate coating dust particles by heterogeneous reactions covered $60-80 \%$ of total sulfate in this study. This would indicate that dust particles shifted sulfates from fine to coarse mode over Eastern China and Pacific in this study. The coating processes also leads dust particles an increase in their hygroscopicity. The change of size distributions of sulfate and nitrate and hygroscopicity could alter aerosol optical properties, direct radiative forcing characteristics and has important implications for regional climate in East Asia (Tang et al., 2004; Liao et al., 2005).

\section{Conclusions}

The objective of this study was to examine the extent to which Asian mineral dust is mixed with anthropogenic pollutants in a super duststorm event during 19-22 March 2010. Meanwhile, influences of mixing processes on regional atmospheric environmental and oceanic biogeochemical cycles were also investigated.

A variety of observational data including in-situ groundbased concentrations of $\mathrm{PM}_{10}$ and its chemical compositions, extinction coefficient data of dust particles from twowavelength Mie-scattering lidar observations, and MODIS satellite AOD550 retrievals were used to validate the performance of the NAQPMS model. The model validation indicates that NAQPMS is capable of reproducing the long-range transport of dust particles from the Gobi desert to the South China Sea and northwestern Pacific. The vertical profile of dust plumes is also reproduced well. Even more importantly, NAQPMS captures the chemical evolution of dust particles during the long-range transport: for example, the increasing concentrations of sulfate, nitrate and $\mathrm{Fe}$ (II).

We found that mixing processes along the trajectory of the long-range transport of Asian dust strongly increased pollutant levels in the dust particles. In Shanghai, a megacity located in the Yangtze River Delta, $\mathrm{SO}_{4}^{2-}$ and $\mathrm{NO}_{3}^{-}$levels captured by minerals reached $\sim 15$ and $10 \mu \mathrm{g} \mathrm{m}^{-3}$, respectively. Even in southern China (Xiamen City), the mixing processes contributed $\sim 60 \%$ of the $\mathrm{SO}_{4}^{2-}$ and $\sim 90 \%$ of the $\mathrm{NO}_{3}^{-}$, with the help of high RH. Analysis based on back trajectories indicates that the active mixing stared in the North China Plain, which is consistent with the distribution of anthropogenic emissions. In general, mixing $\mathrm{SO}_{4}^{2-}$ with minerals made an overall contribution to total sulfate of $\sim 60 \%$ over eastern China and its downwind regions (northwestern Pacific), while its contribution was only $10-20 \%$ in the Gobi. The equivalent contribution of mixed $\mathrm{NO}_{3}^{-}$was 70 $95 \%$ over the Gobi, eastern China and northwestern Pacific. The Fe solubility (the fraction of $\mathrm{Fe}(\mathrm{II})$ in total $\mathrm{Fe}$ ) resulting from oxidization of $\mathrm{SO}_{2}$ on dust particles showed an increase with distance from dust source regions, of the order of $\sim 0.5$ $5 \%$.

The mixing of minerals with pollutants could have important impacts on the atmospheric composition and marine primary productivity over East Asia. In this study, dust particles significantly decreased surface $\mathrm{HNO}_{3}, \mathrm{SO}_{2}$ and $\mathrm{O}_{3}$ by up to $90 \%, 40 \%$ and $30 \%$, respectively, due to the heterogeneous chemistry. We estimated that the Fe(II) deposition in the ocean off East Asia totally reached 327 tons during the 4-day dust event, mostly due to the mixing of minerals with pollutants. The largest deposition occurred in the East China Sea $\left(40-60 \mu \mathrm{g} \mathrm{m}^{-2}\right)$, and in the Sea of Japan and Kuril Islands $\left(100 \mu \mathrm{g} \mathrm{m}^{-2}\right)$. A rough estimation showed that

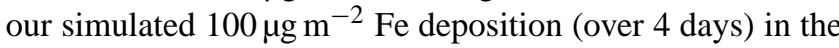
subarctic Pacific(e.g. Kuril Islands) can create a marine primary productivity of $\sim 520 \mathrm{mgC} \mathrm{m}^{-2} \mathrm{~d}^{-1}$, which is consistent with the observed mean marine primary productivity in spring in this region $\left(526 \mathrm{mgC} \mathrm{m}^{-2} \mathrm{~d}^{-1}\right)$. Our results suggest that the $\mathrm{Fe}$ (II) deposition in dust particles has important impact on biological primary marine productivity in subarctic Pacific.

Acknowledgements. This Work is founded by Special Fund for Chinese Environmental Protection Research in the Public Interest (201009002), the CAS Strategic Priority Research Program Grant (No. XDA05100501), NSFC grant (40805051\&41128005) and the great international collaboration project of MOST, China (2010DFA92230). We acknowledge Y. Wang, C. Y. Lin for surface observations at Beijing, Shanghai and Taipei, and R. A. Zaveri for the CBM-Z source. We also thank NIES for providing Lidar data, and MODIS science data support team for satellite-derived AOD550 data.

Edited by: C. K. Chan 


\section{References}

Athanasopoulou, E., Tombrou, M., Pandis, S. N., and Russell, A. G.: The role of sea-salt emissions and heterogeneous chemistry in the air quality of polluted coastal areas, Atmos. Chem. Phys., 8, 5755-5769, doi:10.5194/acp-8-5755-2008, 2008.

Bauer, S. E., Balkanski, Y., Schulz, M., Hauglustaine, D. A., and Dentener, F.: Global modeling of heterogeneous chemistry on mineral aerosol surfaces: Influence on tropospheric ozone chemistry and comparison to observations, J. Geophys. Res-Atmos., 109, D02304, doi:10.1029/2003JD003868, 2004.

Bian, H. S. and Zender, C. S.: Mineral dust and global tropospheric chemistry: Relative roles of photolysis and heterogeneous uptake, J. Geophys. Res.-Atmos., 108, 4672, doi:10.1029/2002jd003143, 2003.

Byun, D. W. and Dennis, R.: Design Artifacts in Eulerian AirQuality Models - Evaluation of the Effects of Layer Thickness and Vertical Profile Correction on Surface Ozone Concentrations, Atmos. Environ., 29, 105-126, 1995.

Charlson, R. J., Lovelock, J. E., Andreae M. O., and Warren, S. G.: A climate feedback loop of sulfate aerosols, Nature, 326, 655661, 1987.

Cheng, T., Gu, X., Xie, D., Li, Z., Yu, T., and Chen, H.: Aerosol optical depth and fine-mode fraction retrieval over East Asia using multi-angular total and polarized remote sensing, Atmos. Meas. Tech., 5, 501-516, doi:10.5194/amt-5-501-2012, 2012.

Choi, J. C., Lee, M., Chun, Y., Kim, J., and Oh, S.: Chemical composition and source signature of spring aerosol in Seoul, Korea, J. Geophys. Res-Atmos., 106, 18067-18074, 2001.

Deng, Z., Han, Y., Bai, H., and Zhao, T.: Effect of dust aerosol production in China mainland on marine primary productivity(in Chinese), China Environmental Science, 28, 872-876, 2008.

Duce, R. A., Unni, C. K., Ray, B. J., Prospero, J. M., and Merrill, J. T.: Long-range atmospheric of soil dust from Asia to the tropical North Pacific: temporal variability, Science, 209, 1522-1524, 1980.

Duckworth, O. W. and Martin, S. T.: Surface complexation and dissolution of hematite by C-1-C-6 dicarboxylic acids at $\mathrm{pH}=5.0$, Geochim. Cosmochim. Ac., 65, 4289-4301, 2001.

Evans, M. J. and Jacob, D. J.: Impact of new laboratory studies of N2O5 hydrolysis on global model budgets of tropospheric nitrogen oxides, ozone, and OH, Geophys. Res. Lett., 32, L09813, doi:10.1029/2005GL022469, 2005.

Fan, S. M., Moxim, W. J., and Levy, H.: Aeolian input of bioavailable iron to the ocean, Geophys. Res. Lett., 33, doi:10.1029/2005GL024852, 2006.

Ginoux, P.: Effects of nonsphericity on mineral dust modeling, J. Geophys. Res.-Atmos., 108, 4052, doi:10.1029/2002JD002516, 2003.

Gratpanche, F. a. J. P. S.: Uptake coefficients of $\mathrm{NO}_{3}$ radicals, J. Chim. Phys., 96, 213-231, 1996.

Guimbaud, C., Arens, F., Gutzwiller, L., Gäggeler, H. W., and Ammann, M.: Uptake of $\mathrm{HNO}_{3}$ to deliquescent sea-salt particles: a study using the short-lived radioactive isotope $\operatorname{tracer}{ }^{13} \mathrm{~N}$, Atmos. Chem. Phys., 2, 249-257, doi:10.5194/acp-2-249-2002, 2002.

Han, X., Zhang, M., Han, Z., Xin, J. Y., Wang, L. L., Qiu, J. H., and Liu, Y. J.: Model analysis of aerosol optical depth distributions over East Asia. Sci. China Earth Sci., 53, 1079-1090, doi:10.1007/s11430-010-3079-z, 2010.
He, K. B., Huo, H., and Zhang, Q.: Urban air pollution in China: current status, characteristics, and progress, Annu. Rev. Energy Env., 27, 397-431, 2002.

Imai, K., Nojiri, Y., Tsurushima, N., and Saino, T.: Time series of seasonal variation of primary productivity at station KNOT (44 degrees N, 155 degrees E) in the sub-arctic western North Pacific, Deep-Sea Res. Pt. II., 49, 5395-5408, 2002.

Jacob, D. J.: Heterogeneous chemistry and tropospheric ozone, Atmos. Environ., 34, 2131-2159, 2000.

Jordan, C. E., Dibb, J. E., Anderson, B. E., and Fuelberg, H. E.: Uptake of nitrate and sulfate on dust aerosols during TRACE-P, J. Geophys. Res.-Atmos., 108, 1-10, 2003.

Kanaya, Y., Pochanart, P., Liu, Y., Li, J., Tanimoto, H., Kato, S., Suthawaree, J., Inomata, S., Taketani, F., Okuzawa, K., Kawamura, K., Akimoto, H., and Wang, Z. F.: Rates and regimes of photochemical ozone production over Central East China in June 2006: a box model analysis using comprehensive measurements of ozone precursors, Atmos. Chem. Phys., 9, 7711-7723, doi:10.5194/acp-9-7711-2009, 2009.

Kim, B. G. and Park, S. U.: Transport and evolution of a wintertime Yellow sand observed in Korea, Atmos. Environ., 35, 31913201, 2001.

Kotamarthi, V. R., Gaffney, J. S., Marley, N. A., and Doskey, P. $\mathrm{V}$.: Heterogeneous $\mathrm{NO}_{\mathrm{x}}$ chemistry in the polluted PBL, Atmos. Environ., 35, 4489-4498, 2001.

Krueger, B. J., Grassian, V. H., Cowin, J. P., and Laskin, A.: Heterogeneous chemistry of individual mineral dust particles from different dust source regions: the importance of particle mineralogy, Atmos. Environ., 38, 6253-6261, 2004.

Lasserre, F., Cautenet, G., Bouet, C., Dong, X., Kim, Y. J., Sugimoto, N., Matsui, I., and Shimizu, A.: A model tool for assessing real-time mixing of mineral and anthropogenic pollutants in East Asia: a case study of April 2005, Atmos. Chem. Phys., 8, 36033622, doi:10.5194/acp-8-3603-2008, 2008.

Li, J., Wang, Z. F., Akimoto, H., Gao, C., Pochanart, P., and Wang, X. Q.: Modeling study of ozone seasonal cycle in lower troposphere over east Asia, J. Geophys. Res-Atmos., 112, D22S25, doi:10.1029/2006JD008209, 2007.

Li, J., Wang, Z., Akimoto, H., Yamaji, K., Takigawa, M., Pochanart, P., Liu, Y., Tanimoto, H., and Kanaya, Y.: Nearground ozone source attributions and outflow in central eastern China during MTX2006, Atmos. Chem. Phys., 8, 7335-7351, doi:10.5194/acp-8-7335-2008, 2008.

Li, J., Wang, Z., Wang, X., Yamaji, K., Takigawa, M., Kanaya, Y., Pochanart, P., Liu, Y., Irie, H., Hu, B., Tanimoto, H., and Akimoto, H.: Impacts of aerosols on summertime tropospheric photolysis frequencies and photochemistry over Central Eastern China, Atmos. Environ., 45, 1817-1829, 2011 a.

Li, J. W., Han, Z. W., and Zhang, R. J.: Model study of atmospheric particulates during dust storm period in March 2010 over East Asia, Atmos. Environ., 45, 3954-3964, doi:10.1016/j.atmosenv.2011.04.068, 2011b.

Liao, H. and Seinfeld, J. H.: Global impacts of gas-phase chemistryaerosol interactions on direct radiative forcing by anthropogenic aerosols and ozone, J. Geophys Res.-Atmos., 110, D18208, doi:10.1029/2005JD005907, 2005.

Luo, C., Mahowald, N. M., Meskhidze, N., Chen, Y., Siefert, R. L., Baker, A. R., and Johansen, A. M.: Estimation of iron solubility from observations and a global aerosol model, J. Geophys. Res.- 
Atmos., 110, D23307, doi:10.1029/2005JD006059, 2005.

Luo, G. and Wang, Z. F.: A global environmental atmospheric transport model (GEATM): Model Description and validation (in Chinese), Chinese Journal of Atmospheric Sciences, 30, 504-518, doi:10.3878/j.issn.1006-9895.2006.03.13, 2006.

Malm, W. C., Day, D. E., and Kreidenweis, S. M.: Light scattering characteristics of aerosols as a function of relative humidity: Part I - A comparison of measured scattering and aerosol concentrations using the theoretical models, J. Air Waste Manage., 50, 686-700, 2000.

Martin, J. H. and Fitzwater, S. E.: Iron deficiency limits phytoplankton growth in the North-east Pacific subarctic, Nature, 331, 341343, 1988.

Martin, R. V., Jacob, D. J., Yantosca, R. M., Chin, M., and Ginoux, P.: Global and regional decreases in tropospheric oxidants from photochemical effects of aerosols, J. Geophys. Res.-Atmos., 108, 4097, doi:10.1029/2002JD002622, 2003.

Maxwell-Meier, K., Weber, R., Song, C., Orsini, D., Ma, Y., Carmichael, G. R., and Streets, D. G.: Inorganic composition of fine particles in mixed mineral dust-pollution plumes observed from airborne measurements during ACE-Asia, J. Geophys. Res.-Atmos., 109, SD19S07, doi:10.1029/2003JD004464,2004.

Meskhidze, N., Chameides, W. L., Nenes, A., and Chen, G.: Iron mobilization in mineral dust: Can anthropogenic SO2 emissions affect ocean productivity?, Geophys. Res. Lett., 30, 2085, doi:10.1029/2003GL018035, 2003.

Nenes, A., Pandis, S. N., and Pilinis, C.: ISORROPIA: A new thermodynamic equilibrium model for multiphase multicomponent inorganic aerosols, Aquat. Geochem., 4, 123-152, 1998.

Okada, K., Heintzenberg, J., Kai, K. J., and Qin, Y.: Shape of atmospheric mineral particles collected in three Chinese arid-regions, Geophys. Res. Lett., 28, 3123-3126, 2001.

Ohara, T., Akimoto, H., Kurokawa, J., Horii, N., Yamaji, K., Yan, X., and Hayasaka, T.: An Asian emission inventory of anthropogenic emission sources for the period 1980-2020, Atmos. Chem. Phys., 7, 4419-4444, doi:10.5194/acp-7-4419-2007, 2007.

Otte, T. L.: The impact of nudging in the meteorological model for retrospective air quality simulations. Part I: Evaluation against national observation networks. J. Appl. Meteor. Climatol., 47, 1853-1867, 2008.

Phadnis, M. J. and Carmichael, G. R.: Numerical investigation of the influence of mineral dust on the tropospheric chemistry of East Asia, J. Atmos. Chem., 36, 285-323, 2000.

Pradhan, M., Kyriakou, G., Archibald, A. T., Papageorgiou, A. C., Kalberer, M., and Lambert, R. M.: Heterogeneous uptake of gaseous hydrogen peroxide by Gobi and Saharan dust aerosols: a potential missing sink for $\mathrm{H}_{2} \mathrm{O}_{2}$ in the troposphere, Atmos. Chem. Phys., 10, 7127-7136, doi:10.5194/acp-10-7127-2010, 2010.

Remer, L. A., Kaufman, Y. J., Tanré, D., Mattoo, S., Chu, D. A., Martins, J. V., Li, R.-R., Ichoku, C., Levy, R. C., Kleidman, R. G., Eck, T. F., Vermote, E., and Holben, B. N.: The MODIS Aerosol Algorithm, Products, and Validation, J. Atmos. Sci., 62, 947-973, doi:10.1175/JAS3385.1, 2005.

Song, C. H. and Carmichael, G. R.: A three-dimensional modeling investigation of the evolution processes of dust and sea-salt particles in east Asia, J. Geophys. Res.-Atmos., 106, 18131-18154, 2001.
Song, C. H., Maxwell-Meier, K., Weber, R. J., Kapustin, V., and Clarke, A.: Dust composition and mixing state inferred from airborne composition measurements during ACE-Asia C130 Flight \#6, Atmos. Environ., 39, 359-369, 2005.

Sugimoto, N., Matsui, I., Shimizu, A., Uno, I., Asai, K., Endoh, T., and Nakajima, T.: Observation of dust and anthropogenic aerosol plumes in the Northwest Pacific with a two-wavelength polarization lidar on board the research vessel Mirai, Geophys. Res. Lett., 29, 1901, doi:10.1029/2002GL015112, 2002.

Sun, Y. L., Zhuang, G. S., Wang, Y., Zhao, X. J., Li, J., Wang, Z. F., and An, Z. S.: Chemical composition of dust storms in Beijing and implications for the mixing of mineral aerosol with pollution aerosol on the pathway, J. Geophys. Res.-Atmos., 110, D24209, doi:10.1029/2005JD006054, 2005.

Sunda, W. G. and Huntsman, S. A.: Interrelated influence of iron, light and cell size on marine phytoplankton growth, Nature, 390, 389-392, 1997.

Tang, Y. H., Carmichael, G. R., Kurata, G., Uno, I., Weber, R. J., Song, C. H., Guttikunda, S. K., Woo, J. H., Streets, D. G., Wei, C., Clarke, A. D., Huebert, B., and Anderson, T. L.: Impacts of dust on regional tropospheric chemistry during the ACE-Asia experiment: A model study with observations, J. Geophys. Res.Atmos., 109, D19S21, doi:10.1029/2003JD003806, 2004.

Tie, X. X., Madronich, S., Walters, S., Edwards, D. P., Ginoux, P., Mahowald, N., Zhang, R. Y., Lou, C., and Brasseur, G.: Assessment of the global impact of aerosols on tropospheric oxidants, J. Geophys. Res.-Atmos., 110, D03204, doi:10.1029/2004JD005359, 2005.

Uno, I., Wang, Z., Chiba, M., Chun, Y. S., Gong, S. L., Hara, Y., Jung, E., Lee, S. S., Liu, M., Mikami, M., Music, S., Nickovic, S., Satake, S., Shao, Y., Song, Z., Sugimoto, N., Tanaka, T., and Westphal, D. L.: Dust model intercomparison (DMIP) study over Asia: Overview, J. Geophys. Res.-Atmos., 111, D12213, doi:10.1029/2005JD006575, 2006.

Vlasenko, A., Sjogren, S., Weingartner, E., Stemmler, K., Gäggeler, H. W., and Ammann, M.: Effect of humidity on nitric acid uptake to mineral dust aerosol particles, Atmos. Chem. Phys., 6, 21472160, doi:10.5194/acp-6-2147-2006, 2006.

Walcek, C. J. and Aleksic, N. M.: A simple but accurate mass conservative, peak-preserving, mixing ratio bounded advection algorithm with Fortran code, Atmos. Environ., 32, 3863-3880, 1998.

Wang, Q. Z., Zhuang, G. S., Li, J. A., Huang, K., Zhang, R., Jiang, Y. L., Lin, Y. F., and Fu, J. S.: Mixing of dust with pollution on the transport path of Asian dust - Revealed from the aerosol over Yulin, the north edge of Loess Plateau, Sci. Total. Environ., 409, 573-581, 2011a.

Wang, S. H., Tsay, S. C., Lin, N. H., Hsu, N. C., Bell, S. W., Li, C., Ji, Q., Jeong, M. J., Hansell, R. A., Welton, E. J., Holben, B. N., Sheu, G. R., Chu, Y. C., Chang, S. C., Liu, J. J., and Chiang, W. L.: First detailed observations of long-range transported dust over the northern South China Sea, Atmos. Environ., 45, 48044808, 2011 b.

Wang, Z. F., Ueda, H., and Huang, M. Y.: A deflation module for use in modeling long-range transport of yellow sand over East Asia, J. Geophys. Res.-Atmos., 105, 26947-26959, 2000.

Wang, Z. F., Akimoto, H., and Uno, I.: Neutralization of soil aerosol and its impact on the distribution of acid rain over east Asia: Observations and model results, J. Geophys. Res.-Atmos., 107, 4389, doi:10.1029/2001JD001040, 2002. 
Wang, Z. F., Li, J., Wang, X. Q., Pochanart, P., and Akimoto, H.: Modeling of regional high ozone episode observed at two mountain sites (Mt. Tai and Huang) in East China, J. Atmos. Chem., 55, 253-272, 2006.

Wei, C.: Modeling the effects of heterogeneous reactions on atmospheric chemistry and aerosol properties, $\mathrm{PhD}$, Chemical and Biochemical Engineering in the Graduate College University of Iowa, Iowa City, Iowa, 2010.

Wesely, M. L.: Parameterization of Surface Resistances to Gaseous Dry Deposition in Regional-Scale Numerical-Models, Atmos. Environ., 23, 1293-1304, 1989.

Wilkening, K. E., Barrie, L. A., and Engle, M.: Atmospheric science - Trans-Pacific air pollution, Science, 290, 65-67, 2000.

Yuan, H., Zhuang, G. S., Li, J., Wang, Z. F., and Li, J.: Mixing of mineral with pollution aerosols in dust season in Beijing: Revealed by source apportionment study, Atmos. Environ., 42, 2141-2157, 2008.

Yue, X., Wang, H. J., Liao, H., and Fan, K.: Simulation of dust aerosol radiative feedback using the GMOD: 2. Dustclimate interactions, J. Geophys. Res.-Atmos., 115, D10202, doi:10.1029/2008JD010995, 2010.

Zaveri, R. A. and Peters, L. K.: A new lumped structure photochemical mechanism for large-scale applications, J. Geophys. Res.Atmos., 104, 30387-30415, 1999.

Zhang, D., Zang, J., Shi, G., Iwasaka, Y., Matsuki, A., and Trochkine, D.: Mixture state of individual Asian dust particles at a coastal site of Qingdao, China, Atmos. Environ., 37, 38953901, doi:10.1016/s1352-2310(03)00506-5, 2003.

Zhang, X. Y., Zhuang, G. S., Chen, J. M., and Xue, H. X.: Speciation of the elements and compositions on the surfaces of dust storm particles: The evidence for the coupling of iron with sulfur in aerosol during the long-range transport, Chinese Sci. Bull., 50, 738-744, 2005.
Zhao, J. P., Zhang, F. W., Xu, Y., Chen, J. S., Yin, L. Q., Shang, X. S., and $\mathrm{Xu}$, L. L.: Chemical Characteristics of Particulate Matter during a Heavy Dust Episode in a Coastal City, Xiamen, 2010, Aerosol Air Qual. Res., 11, 300-309, 2011.

Zheng, C. (Ed.): Atlas of Soil Environmental Background Value in the People's Republic of China. China Environmental Science Press, Beijing, China, 1994.

Zhu, H. and Zhang, H. S.: An estimation of the threshold friction velocities over the three different dust storm source areas in northwest China(in Chinese), Acta. Meteorol. Sin., 68, 977-984, 2010.

Zhu, S., Butler, T., Sander, R., Ma, J., and Lawrence, M. G.: Impact of dust on tropospheric chemistry over polluted regions: a case study of the Beijing megacity, Atmos. Chem. Phys., 10, 38553873, doi:10.5194/acp-10-3855-2010, 2010.

Zhuang, G. S., Yi, Z., and Duce, R.: Link between iron and sulfur cycles suggested by detection of iron(II) in remote marine aerosols, Nature, 355, 537-539, 1992.

Zhuang, G. S., Guo, J. H., Yuan, H., and Zhang, X. Y.: Coupling and feedback between iron and sulphur in air-sea exchange, Chinese Sci. Bull., 48, 1080-1086, 2003.

Zhuang, G. S., Zhang, W. J., Huang, K., Li, J. A., Zhang, R., Wang, Q. Z., Sun, Y. L., Fu, J. S., Chen, Y., Xu, D. Q., and Wang, W.: Mixing and transformation of Asian dust with pollution in the two dust storms over the northern China in 2006, Atmos. Environ., 44, 3394-3403, 2010. 